The following document is a pre-print version of:

Ross, P.-S., White, J.D.L. et McClintock, M. (2008) Geological evolution of the Coombs-Allan Hills area, Ferrar large igneous province, Antarctica: debris avalanches, mafic pyroclastic density currents, phreatocauldrons. Journal of

Volcanology and Geothermal Research 172: 38-60

\title{
Geological evolution of the Coombs-Allan Hills area, Ferrar large igneous province, Antarctica: debris avalanches, mafic pyroclastic density currents, phreatocauldrons...
}

\author{
Pierre-Simon Ross ${ }^{1}$, James D.L. White, and Murray McClintock
}

Department of Geology, University of Otago, PO Box 56, Dunedin, New Zealand

1. Corresponding author

\begin{abstract}
The Jurassic Ferrar large igneous province of Antarctica comprises igneous intrusions, flood lavas, and mafic volcaniclastic deposits (now lithified). The latter rocks are particularly diverse and well-exposed in the Coombs-Allan Hills area of South Victoria Land, where they are assigned to the Mawson Formation. In this paper we use these rocks in conjunction with the pre-Ferrar sedimentary rocks (Beacon Supergroup) and the lavas themselves (Kirkpatrick Basalt) to reconstruct the geomorphological and geological evolution of the landscape. In the Early Jurassic, the surface of the region was an alluvial plain, with perhaps $1 \mathrm{~km}$ of mostly continental siliciclastic sediments underlying it. After the fall of silicic ash from an unknown but probably distal source, mafic magmatism of the Ferrar province began. The oldest record of this event at Allan Hills is a $\leq 180 \mathrm{~m}$-thick debris avalanche deposit (member $\mathrm{m}_{1}$ of the Mawson Formation) which contains globular domains of mafic igneous rock. These domains are inferred to represent dismembered Ferrar intrusions emplaced in the source area of the debris avalanche; shallow emplacement of Ferrar magmas caused a slope failure that mobilized the uppermost Beacon Supergroup, and the silicic ash deposits, into a pre-existing valley or basin.

The period which followed ('Mawson time') was the main stage for explosive eruptions in the Ferrar province, and several cubic kilometres of both new magma and sedimentary rock were fragmented over many years. Phreatomagmatic explosions were the dominant fragmentation mechanism, with magma-water interaction taking place in both sedimentary aquifers and existing vents filled by volcaniclastic debris. At Coombs Hills, a vent complex or 'phreatocauldron' was formed by coalescence of diatreme-like structures; at Allan Hills, member $\mathrm{m}_{2}$ of the Mawson Formation consists mostly of thick, coarse-grained, poorly sorted layers inferred to represent the lithified deposits of pyroclastic density currents. Meanwhile at Carapace Nunatak, mafic clasts were mixed with detrital material to form the Carapace Sandstone in alluvial and eventually lacustrine environments.

Eruptions then became largely effusive, producing hundreds of metres of flood lavas that covered the landscape ('Kirkpatrick time'). In places, lava flowed into ephemeral lakes to form pillow-palagonite breccias (base of sequence, Carapace Nunatak) or pillow lavas (top of sequence, Coombs Hills). Several generations of Ferrrar intrusions were emplaced during the course of these events; at least three can be distinguished based on field relations. New geochemical data indicates that for the Ferrar province, magma involved in the explosive eruptions had the same major element composition as that which produced shallow intrusions and lavas. We also note the possibility that flood lavas were fed by plugs cross-cutting the Mawson Formation at Coombs Hills, rather than by major dikes extending to the surface. Finally, we infer that eruption plumes were limited to the troposphere and that direct environmental impacts were thus likely restricted to the southern hemisphere.
\end{abstract}

Keywords: large igneous province, Ferrar, Antarctica, Mawson Formation, Kirkpatrick Basalt, Coombs Hills, Allan Hills

\section{Introduction}

Many flood basalt provinces contain not only extensive lava flows and some intrusions and silicic pyroclastic deposits, but also variable amounts of mafic volcaniclastic deposits (mostly lithified; see Ross et al., 2005 and Skilling et al., this issue for reviews). At least some of the mafic volcaniclastic rocks in each of the Ferrar, Karoo, and East Greenland provinces were produced relatively early in the provinces' evolution, contain abundant lithic fragments (including numerous quartz grains) derived from sedimentary basements, and include abundant dense to low-vesicularity mafic 
fragments (Hanson and Elliot, 1996; Ukstins Peate et al., 2003; McClintock et al., this issue). Despite these common elements, a considerable diversity of mafic volcaniclastic deposits exists, both within and between provinces.

The Ferrar province of Antarctica (Jurassic, Fig. 1a) has excellent exposures of mafic volcaniclastic deposits associated with flood lavas because of the current level of erosion and the arid climate (see Elliot and Fleming, this issue, for a general presentation on the physical volcanology of this province). One of the best regions to study these rocks, in terms of the quality of the exposures and the diversity of the deposits, is the CoombsAllan Hills area of South Victoria Land (Fig. 1b). In this paper we review information published elsewhere about these rocks and integrate new descriptions and interpretations to build a comprehensive picture of the Jurassic geology of the Coombs-Allan Hills area. New geochemical analyses of the mafic volcaniclastic rocks and the lavas are presented, and the possible environmental impacts of the eruptions are discussed. We then combine these elements in a presentation of the geomorphological and geological evolution of the area.

\subsection{A word on stratigraphy, nomenclature and samples}

The Mawson Formation (mafic volcaniclastic rocks), the Carapace Sandstone (volcaniclastic sandstones), and the Kirkpatrick Basalt (flood lavas) together constitute the extrusive component of the Ferrar large igneous province in South Victoria Land (stratigraphically, these formations are part of the Ferrar Group). The intrusive component (mainly thick sills) is known as the Ferrar Dolerite. Prior to the beginning of Ferrar magmatism, a sedimentary sequence known as the Beacon Supergroup covered the area (Barrett, 1991); the Beacon Supergroup is divided into the Devonian Taylor Group (up to 1.1-1.4 km-thick in South Victoria Land), and the Permian-Triassic Victoria Group ( $\leq 1 \mathrm{~km}$-thick, Fig. 2). This sedimentary sequence covers basement rocks which are dominated by granitoids (e.g., Gunn and Warren, 1962; Smillie, 1992). Herein the use of 'basalt', with the apostrophes, indicates that the word is not meant in the strict geochemical sense, in keeping with the historical usage; we also use the stratigraphic name Kirkpatrick Basalt, without apostrophes, even though the lavas are not strictly basalts. Samples and thin sections referred to in this paper are archived in the collection of the Department of Geology, University of Otago, New Zealand.

\section{Coombs Hills}

Stratigraphic units exposed at Coombs Hills include the Lashly Formation (Victoria Group), the Ferrar Dolerite, the Mawson Formation and the Kirkpatrick Basalt (Fig. 3). The total surface area occupied by the Mawson Formation there is $\sim 28.5 \mathrm{~km}^{2}$ (over half of which is covered by scree or snow; Ross, 2005). Mafic volcaniclastic rocks from this formation can be divided into two facies associations: (a) non-bedded, poorly sorted lapilli-tuffs and tuff-breccias, interpreted to fill a phreatomagmatic vent complex akin to a nest of diatremes (White and McClintock, 2001; McClintock and White, 2005; Ross and White, 2005a); and (b) generally finergrained, layered volcaniclastic rocks overlying, and located beyond the periphery of, the vent complex.

\subsection{The Coombs Hills vent complex}

Salient diatreme-like features of the non-bedded Mawson deposits at Coombs Hills include steeply dipping rafts of country rock and volcaniclastic material inferred to have slumped into vents; steeply dipping contacts between tuff-breccias and/or lapilli-tuffs of contrasting componentry; and abundant in situ peperite and swirly 'basalt' dikes tangled with non-bedded volcaniclastic rock. Poorly sorted lapilli-tuffs and tuff-breccias filling the vent complex north of Mt Brooke can be divided into a number of facies, based on grainsize and componentry (Table 1). The non-bedded rocks are intruded by a variety of bodies which are discussed in Tables 2 and 3, and illustrated in figure 4 (see also Ross and White, 2005b).

A transition zone, a few tens of metres thick, marks the change from non-bedded deposits to clearly layered rocks on the Pyramid (see 2.2 below) and elsewhere. This transition zone displays laterally discontinuous, sub-horizontal lenses rich in finely crystalline 'basalt' fragments, within otherwise massive rocks. The finely crystalline 'basalt' clasts probably represent fragments derived from dikes or crystallized magma plugs, and dominate the initial block-rich layer of the Pyramid sequence (see below).

\subsection{Bedded volcaniclastic deposits}

The Pyramid. Some of the best and thickest exposures of layered volcaniclastic deposits north of Mt Brooke are found on the 'Pyramid' (Fig. 3). It consists of a flat-lying (on the east side) to moderately dipping (on the west side) succession of very thin to very thick beds of tuff-breccia, lapilli-tuff and tuff. The succession on the eastern slopes is characterized by thicker-bedded, structureless to crudely bedded, coarser units, whereas medium to very thin bedded, plane-parallel bedded to cross-stratified units predominate on the western slopes. Beds are mostly laterally persistent for more than $50 \mathrm{~m}$, although single units in the succession may be confined to broad, shallow channels a few metres wide and deep and two prominent tuff-breccia horizons ("block-rich layers") can be traced for more than $200 \mathrm{~m}$ laterally. The latter include lithic blocks up to $1.5 \mathrm{~m}$ long. Normal to rare reverse grading is better developed in lapilli-tuff and tuffgrade units than tuff-breccia; bedding in the latter is defined by clast alignment and abrupt to diffuse upper and lower contacts.

Erosional basal contacts that truncate underlying beds are common low in the succession but become rare up-section, where stacks of very thin to thin-bedded normal-graded lapilli-tuff to tuff units a few metres thick are separated by sharp but conformable contacts. Bedding plane sags are present at the base of a few beds, and are 
especially common at the base of the two prominent tuffbreccia horizons. Bedded rocks on the Pyramid are interpreted as pyroclastic density current and fall deposits laid down on what was then the surface of the Coombs Hills vent complex. Steeper dips on the western flanks of the Pyramid than the eastern slopes hint that original dips were modified by partial subsidence into underlying ventcomplex fill.

The East Ridge. Another interesting exposure of layered volcaniclastic deposits is found on the East Ridge (location 2 on Fig. 3). There, remnants of a constructional volcanic landform form a quarter-circle in map view; the strata now dip toward the inferred vent (northward to north-eastward) at angles of $20-35^{\circ}$ (Ross, 2005). The mafic volcaniclastic deposits are much finer-grained than most of the Mawson Formation, are lighter in colour, and are well bedded (laminated to thickly bedded). Beds consisting of material $\leq 1 \mathrm{~mm}$ make up over $85 \%$ of the deposit's cumulative thickness. Most beds display diffuse to well-developed plane-parallel lamination/bedding, but low-angle $\left(<12^{\circ}\right)$ planar and trough-shaped crosslamination/bedding is also common.

Rim-type accretionary lapilli (Schumacher and Schmincke, 1991) are found only in the upper $4.5 \mathrm{~m}$ of the succession and locally form up to $20 \%$ of single beds, ranging up to $5 \mathrm{~mm}$ diameter. The deposit's material is very rich in sand-sized quartz grains overall, but with an up-section trend of increasing 'basalt' content and concomitant decrease in quartz content. This, and the presence of silicic glass shards (now altered), explains the very pale colour of the lower layers relative to the upper ones.

The arc-shape of the strata suggests that these deposits once formed a circular landform over $200 \mathrm{~m}$ in radius of which only one quarter is preserved, though the original shape in map view may not have been circular (Sohn and Park, 2005). We interpret the bedded succession as the remnants of a tuff ring that partially slumped down into the vent complex. Bedforms, accretionary lapilli, bed thicknesses and arc-shaped outcrop patterns are consistent with deposition of tuff ring material primarily by pyroclastic surges and fall.

The abundance of sand-sized quartz grains and altered silicic shards in the beds argues for country rock excavation and disaggregation by phreatomagmatic explosions. The then-poorly consolidated(?) Lashly Formation, and the tuffaceous sandstones and silicic tuffs that overlay it in the Jurassic (more on this below), are interpreted to be the source of most of the accidental material for the tuff ring. The upward-increasing 'basalt' content in the deposits is interpreted as follows: with time, excavated material is cleared from the vent laterally (although some is recycled), leaving vent-filling debris relatively depleted of accidental material, while new magma enters the vent from below, adding more 'basalt' to the system (Ross, 2005).

\subsection{Kirkpatrick lavas (Mt Brooke)}

Between the highest definite Mawson Formation outcrops on the East Ridge and the summit of Mt Brooke, limited outcrop reveals over $300 \mathrm{~m}$ of tholeiitic lava. Information on these rocks is presented in Table 4; Bradshaw (1987) and McClintock and White (2005) describe the Kirkpatrick succession on other sides of Mt Brooke.

\section{Allan Hills}

Allan Hills exposes the upper three formations of the Beacon Supergroup, the Mawson Formation, and the Ferrar Dolerite, but flood lavas of the Kirkpatrick Basalt are completely eroded (Ross, 2005). The Mawson Formation at Allan Hills occupies $\sim 22.4 \mathrm{~km}^{2}$ (including some scree and snow cover) and is divided into two very distinct members, designated $\mathrm{m}_{1}$ and $\mathrm{m}_{2}$. The former member, atypical in texture and composition, is only exposed in central Allan Hills (Reubi et al., 2005), whereas $\mathrm{m}_{2}$ is compositionally representative of "typical" Mawson Formation, entirely covers the southern Allan Hills (Ross and White, 2005c), and overlies $\mathrm{m}_{1}$ in central Allan Hills (Ross, 2005).

\subsection{Southern Allan Hills}

The base of $m_{2}$ at southern Allan Hills is not exposed and the top has been removed by erosion. Mafic volcaniclastic rocks (Fig. 5) consist principally of thick layers of coarse lapilli-tuff and tuff-breccia ( 1-15 mthick) interpreted as filling a pre-existing topographic depression (Ballance and Watters, 1971; Ross and White, 2005c). Some of these layers might be lahar deposits, but most are inferred to be pyroclastic density current deposits. Rare layers of tuff or fine lapilli-tuff, mostly $\leq 2$ m-thick, are interpreted to have been deposited by dilute currents (Ross and White, 2005c). Many of these fine-grained layers are overlain by laterally continuous block-rich layers several metres thick interpreted to have a ballistic fall component; nearby vents are indicated by huge $(\leq 4 \mathrm{~m})$ blocks and bombs piercing the underlying fine layers (Ross and White, 2005c).

The thick layers of coarse lapilli-tuff and tuffbreccia at southern Allan Hills are compositionally similar to the non-bedded facies at Coombs Hills: both the overall proportions of the facies and the componentry of individual facies are similar; the only exception is an increase of finely crystalline 'basalt' fragments in 'basalt'rich tuff-breccia and lapilli-tuff layers at Allan Hills. This suggests that a Coombs Hills-type complex is a plausible source of these layers, but other evidence shows that one is probably not located right under southern Allan Hills.

The thick volcaniclastic layers of southern Allan Hills are underlain by, and locally interstratified with, thinner layers of plane-parallel to cross-bedded lapilli-tuff and tuff (Fig. 5). These thin layers are inferred to represent base surge deposits for the most part, and some might belong to remnants of tuff rings as in "Tuff Ring Valley". Non-bedded 'basalt'-rich tuff-breccias are present at low elevations, topographically below the layered part of $\mathrm{m}_{2}$ 
(Fig. 5). Outcrop-scale cross-cutting relationships indicate that these rocks are invasive into the layered ones.

\subsection{Central Allan Hills}

Approximately $400 \mathrm{~m}$ of the Mawson Formation is visible in central Allan Hills (basal contact exposed, top eroded off; Fig. 6). Member $\mathrm{m}_{1}$, which is non-bedded and up to $180 \mathrm{~m}$-thick, generally lacks dispersed lapilli-sized fragments of juvenile 'basalt' (which are the key component of "typical" Mawson Formation). Instead, $\mathrm{m}_{1}$ is extremely rich in Beacon Supergroup material, including sandstone megablocks several tens of metres across. The lack of dispersed juvenile fragments precludes an origin as phreatomagmatic eruption-fed mudflows or lahars of the type inferred by Ballance and Watters (1971) or Elliot and Hanson (2001). Member $\mathrm{m}_{1}$ is interpreted by Reubi et al. (2005) as the deposit of a single debris avalanche that flowed into an existing topographic depression. Reubi et al. (2005) infer that the debris avalanche travelled, at least locally, in a north-easterly direction, based on observations in Feistmantel Valley (Fig. 6).

Most of the megablocks in $\mathrm{m}_{1}$ on northern $\mathrm{Mt}$ Watters were derived from the Lashly Formation from a height several hundred metres above their present location (Elliot et al., 2004). Round or smoothly irregular 'basalt' megablocks, which are not internally brecciated, are present in the debris avalanche. These are inferred to represent 'basalt' that reached the depositional site while still sufficiently hot and ductile to resist brittle fragmentation, and thus suggest that inception of Ferrar magmatism at the source of the avalanche, in the form of dikes or sills intruding the Lashly Formation, might have triggered it (Reubi et al., 2005). This implies significant topography and unstable slopes in the source area of the flow.

Mafic volcaniclastic layers $\left(\mathrm{m}_{2}\right)$ conformably overlie $\mathrm{m}_{1}$ at central Allan Hills; these layers are subhorizontal or gently dipping, and include distinctive blockrich horizons similar to those seen in southern Allan Hills. Most of the layers are heterolithological or 'basalt'-rich poorly sorted lapilli-tuffs and tuff-breccias (Ross, 2005).

Both the volcaniclastic layers and $\mathrm{m}_{1}$ are invaded by isolated 'basalt'-rich tuff-breccia bodies (Hood Hills, 2004). Additionally, Beacon-rich lapilli-tuff (LTa) zones and 'basaltic' plugs invade $\mathrm{m}_{1} ; \mathrm{LT}_{\mathrm{a}}$ zones are described and interpreted in Table 5 and figure 7. In contrast to Coombs Hills, at central Allan Hills the debris-filled cross-cutting zones remained isolated from each other, and no extensive complex of mutually cross-cutting vents or diatremes developed.

\section{Carapace Nunatak}

Carapace Nunatak (Fig. 8) is located $\sim 12 \mathrm{~km}$ south of Allan Hills and has good exposures of a generally finer-grained equivalent of the Mawson Formation, the Carapace Sandstone (Ballance and Watters, 1971). This $\sim 120$ m-thick formation (base not exposed) is overlain by several hundred metres of Kirkpatrick flood lavas. Lenses of mafic volcaniclastic deposits containing accretionary lapilli are present within the Kirkpatrick section (details below).

\subsection{Carapace Sandstone}

The Carapace Sandstone consists principally of sandstones and conglomerates which, according to Ballance and Watters (1971), were deposited by "shallow, northeast flowing, ephemeral streams on a subsiding alluvial plain". The highest beds are finer-grained, laminated fossiliferous lake or pond deposits (Ball et al., 1979; Bradshaw, 1987). Mud rip-up clasts in the sandstones just below the mudstones indicate that "pond deposits lower in the sequence [not preserved] were broken up and eroded by further stream action" (Ballance and Watters, 1971). Ross (2005) re-examined sandstone outcrops in the southeastern part of the nunatak (localities 1 and 2 on Fig. 8) and analyzed new thin sections; salient observations are summarized in Table 6 (see also Fig. 9).

Overall the Carapace Sandstone seems to have been deposited in alluvial and lacustrine environments by surface water. No clasts of cemented Mawson Formationlike rocks are present in the sandstones, suggesting that the source of 'basaltic' shards was unconsolidated volcaniclastic material. If the northeast stream flow direction given by Ballance and Watters (1971) is representative, then the explosive volcanic centres of Coombs and Allan Hills can be excluded as the source of 'basaltic' debris (unless the shards were carried southward by eruptive plumes, and re-worked by NE-flowing streams), and we can infer that another explosive centre existed to the southwest of Carapace Nunatak, under the present-day polar plateau, during the Jurassic.

\subsection{Kirkpatrick lavas}

Ballance and Watters (1971) give a $300 \mathrm{~m}+$ thickness for the Kirkpatrick Basalt in their abstract while their stratigraphic column shows a thickness of about 250 m; Bradshaw (1987, p. 38) mentions a thickness of only $164 \mathrm{~m}$, with the apparent greater thickness in previous reports attributed to repetition of some lavas by faulting. Ross (2005) re-examined some of the best lava outcrops and analyzed new thin sections; salient observations are summarized in Table 7 (see also Fig. 10). The first lava and the overlying pillow-palagonite breccia are interpreted as emplaced in a temporary lake, like the top of the Carapace Sandstone (Bradshaw, 1987), whereas the overlying lavas are probably subaerial.

\subsection{Volcaniclastic intervals}

The lava succession is interrupted by volcaniclastic intervals, which are exposed in two main outcrops (localities 3 and 4 on Fig. 8). Salient observations are summarized in Table 8 (see also Fig. 11), but the origin of these rocks is ambiguous. The componentry resembles that of the Mawson Formation, but plane-parallel layering does not point to a specific mode of deposition. Unbroken accretionary lapilli can be found in either primary or resedimented deposits (Boulter, 1987). Beacon Supergroup 
clasts within layers located over $140 \mathrm{~m}$ above the base of the Kirkpatrick sequence suggests that these clasts were transported subaerially by eruption plumes (although Ballance and Watters, 1971, instead propose that the Beacon detritus were derived "from the edge of the basin in which the lavas were accumulating"). Accretionary lapilli also require subaerial eruption plumes, but this does not exclude deposition in water ( $c f$. Bradshaw, 1987). Certainly the coarse tuffs are very similar in composition and structure to Mawson Formation beds of equivalent grainsize at Allan and Coombs Hills.

Similar rocks occur at comparable elevations on nearby Brandau Rocks $\left(30,000 \mathrm{~m}^{2}\right)$, immediately west of Carapace Nunatak (Fig. 8). There, grainsize ranges from coarse ash to small lapilli and bed thickness ranges from laminae to several meters. Accretionary lapilli $\leq 2 \mathrm{~cm}$ make up $15-35 \%$ vol. of some beds (Ross, 2005).

\section{Preliminary geochemistry}

Established chemical types. Two chemical types have been distinguished for Kirkpatrick lavas in North Victoria Land by Fleming et al. (1992) and can be extended throughout the Transantarctic Mountains (Elliot et al., 1999): the volumetrically dominant Mt Fazio Chemical Type (MFCT; mostly basaltic andesites) and the minor Scarab Peak Chemical Type (SPCT; andesites). All known sills and dikes of the Ferrar Dolerite are of general MFCT affinity (Fleming et al., 1997; Elliot et al., 1999), but span a somewhat different range of compositions, as shown on figure 12. MFCT lavas represent $97 \%$ of the inferred original bulk volume of the Kirkpatrick Basalt, with SPCT lavas (always the stratigraphically highest flows) making up the remainder (Elliot et al., 1999). The SPCT is not known from South Victoria Land except in the Prince Albert Mountains (Elliot et al., 1999).

New data. We conducted a preliminary geochemical study at Coombs Hills, Allan Hills, and Carapace Nunatak for two purposes: (i) to verify that the mafic magma responsible for explosive eruptions in the Ferrar large igneous province had the same composition as the lavas and the sills; and (ii) to verify that the Kirkpatrick flood lavas at Mt Brooke and Carapace Nunatak are of MFCT affinity. The ten new analyses (Tables 9 and 10) are shown by bold lozenges on figures 12 and 13. Nine of these plot within the field defined by MFCT lavas (grey squares) and Ferrar Dolerite sills (grey circles); the tenth sample is discussed in a footnote of Table 10.

The new analyses confirm that the lavas at Mt Brooke and Carapace Nunatak are indeed of MFCT affinity. The 'basalt' plugs intruding the vent complex at Coombs Hills and the $m_{1}$ member of the Mawson Formation at central Allan Hills are also chemically similar to MFCT lavas. One clast of finely crystalline 'basalt' within the Mawson Formation at southern Allan Hills also plots within the MFCT field. This indicates that for the Ferrar large igneous province there is no unusual major or trace element chemistry of magma involved in explosive eruptions relative to that involved in effusive flood lava volcanism. Rather, other factors such as eruption rate, availability of external water, etc. were involved in controlling eruption style.

\section{Environmental impacts of Mawson-forming eruptions}

To summarize, the Mawson Formation at Coombs Hills and the $m_{2}$ member at Allan Hills consist largely of poorly sorted, coarse lapilli-tuffs and tuff-breccias. Volume estimates indicate that several cubic kilometres of both mafic magma and Beacon country rock were fragmented to produce these deposits. Significant amounts of fine ash could have been produced as well, but most of the preserved rocks contain only relatively minor amounts $(<10 \%)$ of former fine ash (now altered to clay or optically irresolvable). At Coombs Hills, most of the exposed coarse volcaniclastic material consists of non-bedded rocks filling a vent complex, whereas at southern Allan Hills, it mostly forms thick layers which are interpreted to have been deposited in a paleo-topographic depression. Some of the layers at southern Allan Hills may have been derived from relatively distal vents (perhaps from Coombs Hills in some cases) but much of the debris was likely derived locally, especially the block-rich layers which are very proximal deposits.

Rather than the product of a single cataclysmic eruption (like a caldera-forming eruption), the large volume of volcaniclastic material at Coombs Hills and Allan Hills is inferred to have been formed by numerous small- to moderate-sized eruptions spread over years. At Coombs Hills, rather than a large, circular collapse structure bounded by a caldera-margin fault, and evidence for subsidence of the 'roof' of a magma chamber, one finds numerous small vent structures cross-cutting each other, and it is inferred that the complex grew incrementally over time rather than formed in a single brief event. The general coarseness of the deposits and apparent lack of very widespread tephra fall layers are suggestive of sub-plinian dispersal and eruption plumes less than $10 \mathrm{~km}$ in height. Even though these eruptions took place at high latitudes (e.g., see Fig. 4 of Lawver and Scotese, 1987, for a reconstruction of Gondwana, or McIntosh et al., 1986 for paleomagnetic data) in the southern hemisphere, it seems unlikely that sub-plinian plumes would have penetrated the tropopause on a regular basis. This decreases the likelihood of global environmental impacts. Further, violent magma-water interaction can arrest magma vesiculation early, causing retention of most of the sulphur load in volcanic glass rather than allowing efficient degassing and subsequent injection of gas into the atmosphere (e.g., Thordarson et al., 1996, 2003).

\section{Geomorphological and geological evolution of the Coombs-Allan Hills area}

The distribution and character of mafic volcaniclastic rocks is now used, in conjunction with those of pre-existing sedimentary and sicilic volcaniclastic rocks, and of the flood lavas themselves, to reconstruct the morphological and geological evolution of the Coombs- 
Allan Hills area, drawing information from other regions where applicable.

\subsection{Setting the stage}

The situation in the Late Triassic (and presumably during the Early Jurassic) would have been an alluvial plain with northwest-flowing streams (Figs. 2 and 14a). Silicic ashes of calc-alkaline affinity fell during the Early Jurassic (Collinson et al., 1986; Elliot and Larsen, 1993); it was long thought that such deposits were only preserved in South Victoria Land as clasts and megaclasts within the Mawson Formation (Bradshaw, 1987), but recently Elliot et al. (2004) have described fine-grained sedimentary beds "which include tuffaceous sandstones with silicic glass shards" from Coombs Hills. These authors speculate that a now-eroded sequence of silicic tuffs, perhaps up to $150 \mathrm{~m}$ thick, originally overlay the uppermost Lashly D sedimentary beds at Coombs Hills (Fig. 14b). Correlatives of this sequence are the Hanson Formation (Ferrar Group) in the Central Transantarctic Mountains (Elliot, 1996) and sandstones containing silicic shards capping the Beacon strata in North Victoria Land. Collinson et al. (1986) assigned the latter sandstones to the Section Peak Formation (Beacon Supergroup) but D.H. Elliot (written. commun. to PSR, 2005) now puts them tentatively into the Ferrar Group.

Bryan et al. (2002) suggest that the Hanson Formation may be a distal equivalent of the 188-178 Ma (V1) products of volcanic activity in the silicic Chon Aike province of Patagonia and the Antarctic Peninsula (Pankhurst et al., 2000). However, on trace-element discrimination diagrams, the silicic tuffs in the Central Transantarctic Mountains plot in the "volcanic arc + syncollision" field (Elliot and Larsen, 1993, p. 402), whereas V1 rocks from the Chon Aike have a "within plate" signature (Pankhurst et al., 2000, p. 622).

\subsection{Initiation of Ferrar magmatism: debris avalanches and topographic relief}

The $\mathrm{m}_{1}$ member of the Mawson Formation at Allan Hills appears to record the earliest manifestation of mafic magmatism in South Victoria Land. We infer that $\mathrm{m}_{1}$ is the product of a debris avalanche that was triggered by intrusion of 'basalt' into the Lashly Formation in the source area of the avalanche. At Allan Hills, the Beacon sequence had apparently been eroded down to the Weller Coal Measures or Lower Feather at this stage (although the debris avalanche was probably responsible for some of the erosion now observed). This erosion did not affect the entire Allan Hills area, however, because the Lashly Formation is still exposed in the Roscollyn Tor area (marked 'X' on Fig. 14c). At Coombs Hills, meanwhile, the Beacon Supergroup sequence remained uneroded (and presumably topographically higher), as evidenced by large rafts of Lashly Formation sandstone and silicic tuff now isolated in Mawson Formation within the vent complex.

The occurrence of debris avalanche deposits implies that significant topographic relief and unstable slopes existed in the source area. Such relief, possibly related to extensional tectonics, has also been suggested by Elliot (1992) to explain the great variations in thickness of mafic volcaniclastic deposits and the appearance of large $\mathrm{K}$-feldspar grains in the Hanson Formation (implying basement highs) in the Central Transantarctic Mountains. Note, however, that simple downfaulting does not explain removal of supra-Weller strata prior to debris-avalanche deposition at Allan Hills.

\subsection{Main explosive stage ('Mawson time')}

After emplacement of the $m_{1}$ member of the Mawson Formation at Allan Hills, explosive eruptions dominantly of a phreatomagmatic nature - deposited the $\mathrm{m}_{2}$ member there, while at Coombs Hills the vent complex and overlying layered volcaniclastic rocks were formed (Figs. 14d and 14e). Thick layers in $\mathrm{m}_{2}$ were deposited dominantly by high-concentration pyroclastic density currents, some of which probably travelled $\sim 6 \mathrm{~km}$ from the Coombs Hills vent complex. Low-concentration currents also left finer-grained layers within (and underlying) the thick layers at Allan Hills; at Coombs Hills, such currents formed tuff rings and other layered deposits preserved at the top of the vent complex.

It seems plausible that explosive eruptions also occurred southwest of Carapace Nunatak at this stage, to supply the glassy 'basaltic' clasts in the Carapace Sandstone. A siliciclastic sedimentary system persisted throughout Mawson and Kirkpatrick time, as evidenced for example by lenses of quartzose sandstone near the summit of Mt Brooke. In North Victoria Land, the lava sequence contains sparse beds of fossiliferous lacustrine deposits (Elliot et al., 1986). Elliot and Fleming (this issue) discuss the "interbed facies" in the Kirkpatrick Basalt in more detail. We note that a similar pattern of overlapping volcanic and siliciclastic sedimentation is also seen in the Karoo large igneous province (McClintock et al., this issue), the Etendeka flood basalts (Jerram et al., 2000) and elsewhere.

\subsection{Effusive stage ('Kirkpatrick time')}

After explosive eruptions were largely over, volcanic activity turned to a more effusive style, forming the Kirkpatrick lavas which flooded the landscape, presumably throughout the Transantarctic Mountains (Fig. 14f; although see Elliot and Fleming, 2004). At several sites, early lavas flowed into ephemeral lakes or ponds, forming pillow lavas and hyaloclastite: this is the case at Carapace Nunatak, and at Brimstone Peak in the Prince Albert Mountains (Wilhelm and Wörner, 1996). At Coombs Hills, the pillow lavas occur near the top of the exposed sequence and the underlying flows are considered to be subaerial, confirming the still relatively high-standing nature of the Coombs Hills area in early 'Kirkpatrick time'. We infer, however, that any topographic relief would have been subdued at this stage, given the massive input of volcaniclastic debris and lava filling lowlands. The different stratigraphic position of the subaqueously emplaced lavas at Carapace Nunutak vs. Coombs Hills is 
probably related to differential subsidence/uplift controlled by intrusion of mafic sills at different times combined with a neutral or extensional tectonic regime.

\subsection{Clastic and igneous intrusions}

Finally, the timing of intrusions is of interest.

Isotopic ages of the igneous sills and dikes are

indistinguishable from those of flood lavas (see Riley and Knight, 2001, for a review of Ferrar geochronology). Field relations, however, allow us to define at least three distinct episodes of Ferrar igneous intrusion. First, there are suggestions that major igneous intrusions were emplaced before the start of explosive mafic eruptions (to trigger the $\mathrm{m}_{1}$ debris avalanche, and preserved as globular 'megablocks' of 'basalt' in $\mathrm{m}_{1}$ ). Second, we know that igneous intrusions were emplaced during 'Mawson time' in the Coombs Hills vent complex; some were partially fragmented to form peperite and 'basalt'-rich tuff-breccia zones, with leftover 'basalt' pods (McClintock and White, 2005; Ross and White, 2005a). Third, various igneous intrusions cross-cut Mawson Formation volcaniclastic rocks: (a) thick sills at Allan Hills (Grapes et al., 1974), and perhaps at Coombs Hills (unexposed, but could exist at depth if the model of Ross and White, 2005b for the creation of clastic dikes via elutriation of fine particles above dolerite sills is correct); (ii) plugs, dikes, and thin sills at both Coombs and Allan Hills. Large igneous bodies were also emplaced north and east of the Coombs Hills vent complex (Fig. 3).

The timing of clastic dike emplacement at Coombs Hills, relative to igneous intrusions, is well constrained in relative terms: clastic dikes invade some 'basaltic' plugs, but are cut only by small 'basaltic' dikes. If indeed the plugs are feeders for the Kirkpatrick lavas (Table 2), this implies that clastic dikes were emplaced after the start of 'effusive' activity. If the plugs are not feeders to the lavas, then the clastic dikes could have formed before 'Kirkpatrick time'.

\section{Summary and conclusions}

The Coombs-Allan Hills area of South Victoria

Land is now among the best studied sites for mafic volcaniclastic deposits in the Ferrar large igneous province. In this paper we have presented new details on the physical volcanology of mafic volcaniclastic deposits, lavas and intrusions in this area and briefly reviewed the previously described rock types. We used all these elements to build a picture of the geological and morphological evolution of the landscape, which can be summarized as follows:

- After deposition of siliciclastic rocks in fluvial systems and minor lakes in the Permian and Triassic (Victoria Group), calc-alkaline silicic ash fell in the early Jurassic. This ash was mixed with more siliciclastic debris to form tuffaceous sandstones, possibly throughout the region.

- Then followed an episode of relatively rapid erosion (perhaps with some normal faulting) to create a topographic depression at Allan Hills, but not at
Coombs Hills. A debris avalanche, mobilizing mainly the Lashly Formation and probably triggered by arrival of tholeiitic mafic Ferrar magmas in the uppermost crust, flowed into the topographic depression at Allan Hills.

- The debris-avalanche deposit comprises the base of the Mawson Formation there (member $\mathrm{m}_{1}$ ), and was followed by the main stage of explosive activity, during which the $\mathrm{m}_{2}$ volcaniclastic layers were deposited at Allan Hills and a phreatomagmatic vent complex formed at Coombs Hills.

- Meanwhile, sandstones rich in 'basaltic' detritus were deposited on an alluvial plain in the Carapace Nunutak area. Eventually a lake developed there, so that the uppermost Carapace Sandstone beds are lacustrine.

- The eruptions then changed in nature, with effusion of lavas replacing phreatomagmatic explosions, to form the Kirkpatrick flood lavas. This transition is represented in sediments and pillow lavas at Carapace Nunatak, but not at Coombs Hills; there, subaqueous deposition is only clear near the top of the exposed lava pile. The different position of subaqueous lavas at the two sites probably implies differential ground movement due to sill intrusion.

- Several episodes of igneous intrusions (Ferrar Dolerite) can be recognized based on field relationships.

\section{Acknowledgements}

The submitted manuscript was completed while PSR was visiting the Institut für Geologie at Würzburg University, Germany; the people of the institute are thanked for a warm welcome. PSR also acknowledges M. Jébrak for hosting him at Université du Québec à Montréal (Canada) during the revision of the manuscript. Our work on the Ferrar province was supported by Antarctica New Zealand (logistical support and the Sir Robin Irvine Scholarship to PSR), the University of Otago, and the Fonds québécois de recherche sur la nature et les technologies (Canada). J. Cottle and R. Brown served faithfully as field guides, while A. Aitken, M. Baker and T. Barry were field assistants. We thank D. Walls, B. Pooley and S. Read for technical support, and D.H. Elliot and M. Ort for helpful reviews.

\section{References}

Antonini, P., Piccirillo, E.M., Petrini, R., Civetta, L., D'Antonio, M., Orsi, G., 1999. Enriched mantle Dupal signature in the genesis of the Jurassic Ferrar tholeiites from Prince Albert Mountains (Victoria Land, Antarctica). Contrib. Mineral. Petrol. 136, 1-19.

Ballance, P.F., Watters, W.A., 1971. The Mawson Diamictite and the Carapace Sandstone, formations of the Ferrar Group at Allan Hills and Carapace Nunatak, Victoria Land, Antarctica. N. Z. J. Geol. Geophys. 14, 512-527.

Ball, H.W., Borns, H.W., Hall, B.A., Brooks, H.K., Carpenter, F.M., Delevoryas, T., 1979. Biota, age, 
and significance of lake deposits, Carapace Nunatak, Victoria Land, Antarctica. In: Lasker, B., Rao, C.S.R. (Eds.), Fourth International Gondwana Symposium. Hindustan Publishing Corporation, Delhi, pp. 166-175.

Barrett, P.J., 1991. The Devonian to Jurassic Beacon Supergroup of the Transantarctic Mountains and correlatives in other parts of Antarctica. In: Tingey, R.J. (Ed.), The Geology of Antarctica. Oxford University Press, Oxford, pp. 120-152.

Barrett, P.J., Kohn, B.P., 1975. Changing sediment transport directions from Devonian to Triassic in the Beacon Super-group of South Victoria Land, Antarctica. In: Campbell, K.S.W. (Editor), Gondwana Geology. A.N.U. Press, Canberra, pp. 15-35.

Boulter, C.A., 1987. Subaqueous deposition of accretionary lapilli: significance for palaeoenvironmental interpretations in Achaean greenstone belts. Precambrian Res. 34, 231-246.

Bradshaw, M.A., 1987. Additional field interpretation of the Jurassic sequence at Carapace Nunatak and Coombs Hills, south Victoria Land, Antarctica. N. Z. J. Geol. Geophys. 30, 37-49.

Bradshaw, M.A., 1991. The Devonian Pacific margin of Antarctica. In: Thomson, M.R.A., Crame, J.A., Thomson, J.W. (Eds.), Geological Evolution of Antarctica. Cambridge University Press, Cambridge, pp. 193-197.

Bryan, S.E., Riley, T.R., Jerram, D.A., Stephens, C.J., Leat, P.L., 2002. Silicic volcanism: An undervalued component of large igneous provinces and volcanic rifted margins. In: Menzies, M.A., Klemperer, S.L., Ebinger, C.J., Baker, J. (Eds.), Volcanic Rifted Margins. Geological Society of America Special Paper 362, pp. 97-118.

Collinson, J.W., Pennington, D.C., Kemp, N.R., 1986. Stratigraphy and petrology of Permian and Triassic fluvial deposits in northern Victoria Land, Antarctica. In: Stump, E. (Editor), Geological Investigations in Northern Victoria Land. Antarctic Research Series 46, pp. 211-242.

Demarchi, G., Antonini, P., Piccirillo, E.M., Orsi, G., Civetta, L., D'Antonio, M., 2001. Significance of orthopyroxene and major element constraints on the petrogenesis of Ferrar tholeiites from southern Prince Albert Mountains, Victoria Land, Antarctica. Contrib. Mineral. Petrol. 142, 127146.

Elliot, D.H., 1972. Major oxide chemistry of the Kirkpatrick Basalt, Central Transantarctic Mountains. In: Adie, R.J. (Ed.), Antarctic Geology and Geophysics. Universitetsforlagets, Oslo, pp. 413-418.

Elliot, D.H., 1992. Jurassic magmatism and tectonism associated with Gondwanaland break-up: an Antarctic perspective. In: Storey, B.C., Alabaster, T., Pankhurst, R.J. (Eds.), Magmatism and the
Causes of Continental Break-up. Geological Society Special Publication 68, pp. 165-184.

Elliot, D.H., 1996. The Hanson Formation: a new stratigraphical unit in the Transantarctic Mountains, Antarctica. Antarctic Sci. 8, 389-394.

Elliot, D.H., 2000. Stratigraphy of Jurassic pyroclastic rocks in the Transantarctic Mountains. J. African Earth Sci. 31, 77-89.

Elliot, D.H., Larsen, D., 1993. Mesozoic volcanism in the central Transantarctic Mountains, Antarctica: Depositional environment and tectonic setting. In: Findlay, R.H., Unrug, R., Banks, M.R., Veerers, J.J. (Eds.), Assembly, evolution and dispersal; proceedings of the Gondwana Eight symposium. Balkema, Rotterdam, pp. 397-410.

Elliot, D.H., Hanson, R.E., 2001. Origin of widespread, exceptionally thick basaltic phreatomagmatic tuff breccia in the Middle Jurassic Prebble and Mawson Formations, Antarctica. J. Volcanol. Geotherm. Res. 111, 183-201.

Elliot, D.H., Fleming, T.H., 2004. Occurrence and dispersal of magmas in the Jurassic Ferrar Large Igneous Province, Antarctica. Gondwana Research 7, 223-237.

Elliot, D.H., Fleming, T.H., this issue. Physical Volcanology of the Ferrar Large Igneous Province, Antarctica. J. Volcanol. Geotherm. Res.

Elliot, D.H., Siders, M.A., Haban, M.A., 1986. Jurassic tholeiites in the region of the upper Rennick Glacier, North Victoria Land. In: Stump, E. (Ed.), Geological Investigations in Northern Victoria Land. Antarctic Research Series 46, pp. 249-265.

Elliot, D.H., Fleming, T.H., Kyle, P.R., Foland, K.A., 1999. Long-distance transport of magmas in the Jurassic Ferrar Large Igneous Province, Antarctica. Earth Planet. Sci. Lett. 167, 89-104.

Elliot, D.H., Fortner, T., Grimes, C.B., 2004. BeaconMawson field relations at Allan and Coombs Hills, south Victoria Land. In: Hubberten, H.-W. (Ed), Proceedings of the ninth international symposium on Antarctic earth sciences, Postdam (Germany).

Fleming, T.H., Elliot, D.H., Jones, L.M., Bowman, J.R., Siders, M.A., 1992. Chemical and isotopic variations in an iron-rich flow from the Kirkpatrick Basalt, north Victoria Land, Antarctica: implications for low-temperature alteration. Contrib. Mineral. Petrol. 111, 440-457.

Fleming, T.H., Foland, K.A., Elliot, D.H., 1995. Isotopic and chemical constraints on the crustal evolution and source signature of Ferrar magmas, North Victoria Land, Antarctica. Contrib. Mineral. Petrol. 121, 217-236.

Fleming, T.H., Heimann, A., Foland, K.A., Elliot, D.H., 1997. ${ }^{40} \mathrm{Ar} /{ }^{39} \mathrm{Ar}$ geochronology of Ferrar Dolerite sills from the Transantarctic Mountains, Antarctica: Implications for the age and origin of the Ferrar magmatic province. Geol. Soc. Am. Bull. 109, 533-546. 
Ford, A.B., Kistler, R.W., 1980. K-Ar age, composition, and origin of Mesozoic mafic rocks related to the Ferrar Group, Pensacola Mountains, Antarctica. N. Z. J. Geol. Geophys. 23, 371-390.

Grapes, R.H., Reid, D.L., McPherson, J.G., 1974. Shallow dolerite intrusion and phreatic eruption in the Allan Hills region, Antarctica. N. Z. J. Geol. Geophys. 17, 563-577.

Gunn, B.M., Warren, G., 1962. Geology of Victoria Land between the Mawson and Murlock Glaciers, Antarctica. N. Z. Geol. Soc. Bull. 71, 157 pp.

Hanson, R.E., Elliot, D.H., 1996. Rift-related Jurassic phreatomagmatism in the central Transantarctic Mountains: precursory stage to flood-basalt effusion. Bull. Volcanol. 58, 327-347.

Head, J.W., Wilson, L., 1989. Basaltic pyroclastic eruptions: influence of gas-release patterns and volume fluxes on fountain structure, and the formation of cinder cones, spatter cones, rootless flows, lava ponds and lava flows. J. Volcanol. Geotherm. Res. 37, 261-271.

Hergt, J.M., Chappell, B.W., Faure, G., Mensing, T.M., 1989. The geochemistry of Jurassic dolerites from Portal Peak, Antarctica. Contrib. Mineral. Petrol. 102, 298-305.

Hood Hills, S.B., 2004. Internal features of a single vent structure within a large phreatomagmatic vent complex, Allan Hills, Antarctica. MSc Thesis, University of Otago, Dunedin.

Hooper, P.R., 2000. Flood basalt provinces. In: Sigurdsson, H., Houghton, B., McNutt, S.R., Rymer, H., Stix, J. (Eds.), Encyclopedia of Volcanoes. Academic Press, London, pp. 345359.

Houghton, B., Wilson, C.J.N., 1989. A vesicularity index for pyroclastic deposits. Bull. Volcanol. 51, 451462.

Irvine, T.N., Baragar, W.R.A., 1971. A guide to the chemical classification of common volcanic rocks. Can. J. Earth Sci. 8, 523-548.

Isaac, M.J., Chinn, T.J., Edbrooke, S.W., Forsyth, P.J., 1996. Geology of the Olympus Range area, southern Victoria Land, Antarctica. Geological Map 20, Scale 1:50,000, folded in the accompanying report, Inst. Geol. Nucl. Sci., Lower Hutt, New Zealand.

Jerram, D.A., Mountney, N.P., Howell, J.A., Long, D., Stollhofen, H., 2000. Death of a sand sea: an active aeolian erg systematically buried by the Etendeka flood basalts of NW Namibia. J. Geol. Soc. [London] 157, 513-516.

Kyle, P.R., Pankhurst, R.J., Bowman, J.R., 1983. Isotopic and chemical variations in Kirkpatrick Basalt Group rocks from southern Victoria Land. In: Oliver, R.L., James, P.R., Jago, J.B. (Eds.), Antarctic Earth Science; forth international symposium, pp. 234-237.

Lawver, L.A., Scotese, C.R., 1987. A revised reconstruction of Gondwanaland. In: McKenzie,
G.D. (Editor), Gondwana Six: Structure, Tectonics, and Geophysics. Am. Geophys. Union, Geophys. Mono. 40, pp. 17-23.

Le Maître, R.W., 1989. A classification of igneous rocks and glossary of terms. Blackwell, Oxford, $193 \mathrm{pp}$.

Long, P.E., Wood, B.J., 1986. Structures, textures, and cooling histories of Columbia River Basalt flows. Geol. Soc. Am. Bull. 97, 1144-1155.

Lyle, P., 2000. The eruption environment of multi-tiered columnar basalt flows. J. Geol. Soc. [London] $157,715-722$.

McClintock, M.K., 2001. Phreatomagmatism at Coombs Hills, Antarctica - Magma-water supervolcanism in a wet, failed rift. MSc Thesis, University of Otago, Dunedin, New Zealand, 189 p.

McClintock, M.K., White, J.D.L., 2005. Large-volume phreatomagmatic vent complex at Coombs Hills, Antarctica records wet, explosive initiation of flood basalt volcanism in the Ferrar LIP. Bull. Volcanol. (in press)

McClintock, M., White, J.D.L., Houghton, B.F., Skilling, I.P., this issue. Physical volcanology of a large crater-complex within the Karoo flood basalt, Sterkspruit, South Africa. J. Volcanol. Geotherm. Res.

McIntosh, W.C., Kyle, P.R., Sutter, J.F., 1986. Paleomagnetic results from the Kirkpatrick basalt group, Mesa Range, North Victoria Land, Antarctica. In: Stump, E. (Ed), Geologic investigations in northern Victoria Land. American Geophysical Union, Antarctic Research Series, 46, pp. 289-303.

Mensing, T.M., Faure, G., Jones, L.M., Bowman, J.R., Hoefs, J., 1984. Petrogenesis of the Kirkpatrick Basalt, Solo Nunatak, Northern Victoria Land, Antarctica, based on isotopic compositions of strontium, oxygen and sulfur. Contrib. Mineral. Petrol. 87, 101-108.

Pankhurst, R.J., Riley, T.R., Fanning, C.M., Kelley, S.P., 2000. Episodic silicic volcanism in Patagonia and the Antarctic Peninsula: chronology of magmatism associated with the break-up of Gondwana. J. Petrol. 41, 605-625.

Pocknall, D.T., Chinn, T.J., Sykes, R., Skinner, D.N.B., 1994. Geology of the Convoy Range area, southern Victoria Land, Antarctica, Geological Map 11, Scale 1:50,000, folded in the accompanying report, Institute of Geological and Nuclear Sciences, Lower Hutt, New Zealand.

Reubi, O., Ross, P.-S., White, J.D.L., 2005. Debris avalanche deposits associated with Large Igneous Province volcanism: an example from the Mawson Formation, Central Allan Hills, Antarctica. Geol. Soc. Am. Bull. (in press)

Riley, T.R., Knight, K.B., 2001. Age of pre-break-up Gondwana magmatism. Antarctic Sci. 13, 99-110.

Ross, P.-S., 2005. Volcanology of the Mawson Formation at Coombs and Allan Hills, South Victoria Land, 
Antarctica. PhD thesis, University of Otago, Dunedin, New Zealand.

Ross, P.-S., White, J.D.L., 2005a. Debris jets in continental phreatomagmatic volcanoes: a field study of their subterranean deposits in the Coombs Hills vent complex, Antarctica. J. Volcanol. Geotherm. Res. doi:10.1016/j.jvolgeores.2005.06.007.

Ross, P.-S., White, J.D.L., 2005b. Unusually large clastic dykes formed by elutriation of a poorly sorted, coarser-grained source. J. Geol. Soc. [London] 162, 579-582.

Ross, P.-S., White, J.D.L., 2005c. Mafic, large-volume, pyroclastic density current deposits from phreatomagmatic eruptions in the Ferrar large igneous province, Antarctica. J. Geol. 113, 627649.

Ross, P.-S., Ukstins Peate, I., McClintock, M.K., Xu, Y.G., Skilling, I.P., White, J.D.L., Houghton, B.F., 2005. Mafic volcaniclastic deposits in flood basalt provinces: a review. J. Volcanol. Geotherm. Res. 145, 281-314.

Schumacher, R., Schmincke, H.-S., 1991. Internal structure and occurrence of accretionary lapilli - a case study at Laacher See Volcano. Bull. Volcanol. 53, 612-634.

Self, S., Thordarson, T., Keszthelyi, L., 1997. Emplacement of continental basalt lava flows. In: Mahoney, J.J., Coffin, M.F. (Eds.), Large Igneous Provinces: Continental, Oceanic, and Planetary Flood Volcanism. Am. Geophys. Union, Geophys. Mono. 100, pp. 381-410.

Siders, M.A., Elliot, D.H., 1985. Major and trace element geochemistry of the Kirkpatrick Basalt, Mesa Range, Antarctica. Earth Planet. Sci. Lett. 72, 5464.

Skilling, I.P., White, J.D.L., Self, S., Ross, P.-S., Bryan, S., this issue. J. Volcanol. Geotherm. Res.

Smillie R.W., 1992. Suite subdivision and petrological evolution of granitoids from the Taylor Valley and Ferrar Glacier region, South Victoria Land. Antarctic Sci. 4, 71-87.

Sohn, Y.K., Park, K.H., 2005. Composite tuff ring/cone complexes in Jeju Island, Korea: possible consequences of substrate collapse and vent migration. J. Volcanol. Geotherm. Res. 141, 157175.
Stump, E., 1995. The Ross Orogen of the Transantarctic Mountains. Cambridge University Press, Cambridge, 284 pp.

Swanson, D.A., 1973. Pahoehoe Flows from the 19691971 Mauna Ulu Eruption, Kilauea Volcano, Hawaii. Geol. Soc. Am. Bull. 84, 615-626.

Swanson, D.A., Wright, T.L., Helz, R.T., 1975. Linear vent systems and estimated rates of magma production and eruption for the Yakima Basalt on the Columbia Plateau. Am. J. Sci. 275, 877-905.

Thordarson, T., Self, S., 1993. The Laki (Skaftár Fires) and Grímsvötn eruptions in 1783-1785. Bull. Volcanol. 55, 233-263.

Thordarson, T., Self, S., Óskarsson, N., Hulsebosch, T., 1996. Sulfur, chlorine, and fluorine degassing and atmospheric loading by the 1783-1784 AD Laki (Skaftár Fires) eruption in Iceland. Bull. Volcanol. $58,205-225$.

Thordarson, T., Self, S., Miller, D.J., Larsen, D., Vilmundardóttir, E.G., 2003. Sulphur release from flood lava eruptions in the Veidivötn, Grímsvötn and Katla volcanic systems, Iceland. In: Oppenheimer, C., Pyle, D.M., Barclay, J. (Eds.), Volcanic Degassing. Geological Society [London] Special Publication 213, pp. 103-121.

Ukstins Peate, I., Larsen, M., Lesher, C.E., 2003. The transition from sedimentation to flood volcanism in the Kangerlussuaq Basin, East Greenland: basaltic pyroclastic volcanism during initial Palaeogene continental break-up. J. Geol. Soc. [London] 160, 759-772.

White, J.D.L., McClintock, M.K., 2001. Immense vent complex marks flood-basalt eruption in a wet, failed rift: Coombs Hills, Antarctica. Geology [Boulder] 29, 935-938.

Wihelm, S., Wörner, G., 1996. Crystal size distribution in Jurassic Ferrar flows and sills (Victoria Land, Antarctica): evidence for processes of cooling, nucleation, and crystallisation. Contrib. Mineral. Petrol. 125, 1-15.

Wilson, L., Head, J.W., 1981. Ascent and eruption of basaltic magma on the Earth and Moon. J. Geophys. Res. 86, 2971-3001.

Winchester, J.A., Floyd, P.A., 1977. Geochemical discrimination of different magma series and their differentiation products using immobile elements. Chem. Geol. 20, 325-343. 
Table 1

Facies descriptions and interpretations for the non-bedded, poorly sorted volcaniclastic rocks in the Mawson Formation north of Mt Brooke at Coombs Hills, after Ross (2005) and Ross and White (2005a)

\begin{tabular}{|c|c|c|}
\hline Facies & Observations & Interpretations \\
\hline $\begin{array}{l}\text { Heterolithologic } \\
\text { lapilli-tuff }\left(\mathrm{LT}_{\mathrm{h}}\right)\end{array}$ & $\begin{array}{l}\text { 1- volumetrically dominant facies (locally a tuff-breccia) } \\
\text { 2- lacks bedding planes for }>300 \text { vertical metres } \\
\text { 3- lateral variations in grainsize \& componentry are } \\
\text { observed, but no systematic vertical variations } \\
\text { 4- consists of glassy 'basalt' fragments (mostly blocky } \\
\text { ones), sand-grade detrital quartz particles, Beacon } \\
\text { fragments, composite (recycled peperite) clasts \& rare } \\
\text { granite fragments } \\
\text { 5- 'basaltic' clasts are variably vesicular, most being } \\
\text { dense to incipiently vesicular (vesicularity index of } \\
\text { Houghton \& Wilson, 1989) } \\
\text { 6- host for LT } \mathrm{T}_{\mathrm{a}} \text { and TB } \mathrm{B}_{\mathrm{j}} \text { zones } \\
\text { 7- hosts rafts of Lashly Formation (sandstone to } \\
\text { siltstone), plus silicic tuff and silicic tuffaceous } \\
\text { sandstone \& rafts of layered, fine-grained, mafic } \\
\text { volcaniclastic rocks (some containing accretionary } \\
\text { lapilli); most of these rafts dip steeply }\end{array}$ & $\begin{array}{l}\text { - clast assemblage suggests phreatomagmatic } \\
\text { eruptions affecting upper part of Beacon } \\
\text { sequence, occasionally as far down as base of } \\
\text { Victoria Gp } \\
\text { - an origin as one or several lahars (Hanson \& } \\
\text { Elliot, 2001) - or subaerial pyroclastic flows - } \\
\text { filling a pre-existing topographic depression is } \\
\text { not favoured because of observations } 2,3 \text { \& } 7 \\
\text { - emplacement in a vent complex by subterranean } \\
\text { debris jets } \\
\text { - several cycles of eruption probably necessary to } \\
\text { reach proportions of glassy 'basalt' clasts } \\
\text { observed in } \mathrm{LT}_{\mathrm{h}}\end{array}$ \\
\hline $\begin{array}{l}\text { Beacon-rich } \\
\text { lapilli-tuff }\left(\mathrm{LT}_{\mathrm{a}}\right)\end{array}$ & $\begin{array}{l}\text { - forms steep, pipe-like bodies cross-cutting } \mathrm{LT}_{\mathrm{h}} \text {, with } \\
\text { sharp contacts } \\
\text { - locally a tuff-breccia } \\
\text { - outlines in map view are generally simple, elliptical in } \\
\text { shape, long axis length a few dm to a few } 100 \mathrm{~s} \mathrm{m,} \\
\text { aspect ratio } 0.2-0.8 \\
\text { - same types of clasts as } \mathrm{LT}_{\mathrm{h}} \text {, but with more abundant } \\
\text { country rock fragments }\end{array}$ & $\begin{array}{l}\text { - phreatomagmatic fragmentation, vent complex } \\
\text { setting } \\
\text { - formed by Beacon-rich subterranean debris jets } \\
\text { - jets originated when phreatomagmatic explosions } \\
\text { occurred near walls or floor of vent complex, } \\
\text { causing fragmentation of abundant Victoria Gp } \\
\text { material }\end{array}$ \\
\hline $\begin{array}{l}\text { 'Basalt'-rich tuff- } \\
\text { breccia }\left(\mathrm{TB}_{\mathrm{j}}\right)- \\
\text { general }\end{array}$ & $\begin{array}{l}\text { - forms zones, m- to } 100 \mathrm{~s} \text { of m-wide, cross-cutting } \mathrm{LT}_{\mathrm{h}} \\
\text { - locally a lapilli-tuff } \\
\text { - contains more vesicular 'basaltic' clasts than in other } \\
\text { facies (except } \mathrm{TB}_{\mathrm{hr}} \text { ) } \\
\text { - no more than } 5 \% \text { Beacon clasts in the lapilli + block } \\
\text { size fraction }\end{array}$ & - vent complex setting \\
\hline $\mathrm{TB}_{\mathrm{j}}-$ type 1 & $\begin{array}{l}\text { - often relatively sharp contacts with host, relatively } \\
\text { compact shapes } \\
\text { - same types of clasts as } \mathrm{LT}_{\mathrm{h}} \text {, but with more abundant } \\
\text { basaltic fragments; blocky 'basalt' clasts present } \\
\text { - not strongly associated with basalt pods and/or peperite } \\
\text { domains }\end{array}$ & $\begin{array}{l}\text { - phreatomagmatic fragmentation } \\
\text { - debris jets propelled by explosions taking place } \\
\text { well away from country rocks } \\
\text { - material in jets richer in 'basalt' than surrounding } \\
\text { LT }_{\mathrm{h}} \text { debris because of addition of juvenile basalt }\end{array}$ \\
\hline $\mathrm{TB}_{\mathrm{j}}-$ type 2 & $\begin{array}{l}\text { - abundant in the West Ridge area (Fig. 3) } \\
\text { - generally diffuse gradational contacts with host, } \\
\text { outlines can be very complex (e.g., octopus-like) } \\
\text { - contains fluidal 'basalt' fragments and composite } \\
\text { clasts, and few or no blocky clasts } \\
\text { - spatially associated with in situ peperite domains, } \\
\text { and/or pods of glassy 'basalt' }\end{array}$ & $\begin{array}{l}\text { - somewhat less violent origin than for } \mathrm{LT}_{\mathrm{a}} \mathrm{LT}_{\mathrm{h}} \text { and } \\
\text { type } 1 \mathrm{~TB}_{\mathrm{j}} \text { zones } \\
\text { - juvenile clast-forming processes inferred to be } \\
\text { similar to those in peperite (mostly non- } \\
\text { explosive, e.g., surface tension effects, magma- } \\
\text { 'sediment' density contrasts, instabilities in } \\
\text { vapour films, etc.) } \\
\text { - mixing of juvenile fragments with surrounding } \\
\text { volcaniclastic material (incorporation of quartz } \\
\text { grains, etc.) }\end{array}$ \\
\hline $\begin{array}{l}\text { "Raggy" } \\
\text { heterolithologic } \\
\text { tuff-breccia }\left(\mathrm{TB}_{\mathrm{hr}}\right)\end{array}$ & $\begin{array}{l}\text { - volumetrically minor } \\
\text { - tuff-breccia version of } \mathrm{LT}_{\mathrm{h}} \text { with abundant "rags" } \\
\text { - rags = relatively vesicular, glassy 'basaltic' fragments, } \\
\text { elongate, up to several dm long, w/ bended shapes, } \\
\text { delicate ends forming spiral shapes \& displaying }\end{array}$ & $\begin{array}{l}\text { - rags transported while still plastic (high } \\
\text { temperature) } \\
\text { - } \mathrm{LT}_{\mathrm{h}} \text {-type material simultaneously transported } \\
\text { with rags was probably cool (quenched, blocky } \\
\text { basalt clasts and Beacon material) } \\
\text { - zones containing 'randomly' or sub-vertically }\end{array}$ \\
\hline
\end{tabular}


accommodation of surrounding clasts

- rags can be aligned in any orientation or be 'randomly' dispersed aligned rags could have formed when phreatomagmatic explosions accelerated vesiculating melt not directly involved in the explosions

- zones containing sub-horizontally aligned rags are difficult to explain

Table 2

Facies descriptions and interpretations for intrusive rocks in the vent complex north of Mt Brooke at Coombs Hills, after Ross (2005)

\begin{tabular}{|c|c|}
\hline Facies & Observations \& interpretations \\
\hline & $\begin{array}{l}\text { - Plug-shaped igneous intrusions, } 10 \text { s to } 100 \mathrm{~s} \text { m across (e.g., Fig. 4); most have circular or elliptical shapes in map view } \\
\text { \& consist of non-vesicular, finely crystalline 'basalt' } \\
\text { - Jointing patterns \& textural variations indicate that at least some plugs were formed by multiple magma injections } \\
\text { - In most flood basalt fields, lavas are inferred to have been fed by fissures (e.g., Columbia River Basalts: Swanson et al., } \\
\text { 1975; Hooper, 2000); however, plugs could accomplish the same function } \\
\text { - Modelling of basalt flow in the Earth's crust following Wilson \& Head (1981) indicates that a vertical cylindrical } \\
\text { conduit } 10 \mathrm{~m} \text { in radius can sustain a magma flow of } 3.4 \times 10^{7} \mathrm{~kg} / \mathrm{s} \text { (Table } 3 \text { ) } \\
\text { - Mapped plugs at Coombs Hills } \leq 200 \mathrm{~m} \text { across: even if full width of a plug not filled with flowing magma at any given } \\
\text { time, mass eruption rates sufficient to feed typical flood lavas are readily achievable (mean rate for Roza } \\
\sim 1.1 \times 10^{7} \mathrm{~kg} / \mathrm{s} \text {; peak rate for Laki } \sim 1.2 \times 10^{7} \mathrm{~kg} / \mathrm{s} \text {; see Thordarson \& Self, } 1993 \text { and Self et al., 1997) }\end{array}$ \\
\hline $\begin{array}{l}\text { Clastic } \\
\text { dikes }\end{array}$ & $\begin{array}{l}\text { - Cross-cut both non-bedded \& bedded parts of Mawson Formation plus 'basalt' plugs (Fig. 4) } \\
\text { - Most common type of dike consists of homogeneous, light brown to beige tuff, often with wall-parallel laminated } \\
\text { margins \& lacks clear evidence for multiple injections } \\
\text { - Largest is } 75 \text { m-wide, amongst the largest exposed clastic dikes on Earth } \\
\text { - See Ross and White (2005b) for more detail and a new genetic model }\end{array}$ \\
\hline $\begin{array}{l}\text { 'Basalt' } \\
\text { dikes \& } \\
\text { sills }\end{array}$ & $\begin{array}{l}\text { - 'Basalt' dikes, } 10 \mathrm{~cm} \text { to } 5 \mathrm{~m} \text {-wide, cross-cut every other rock-type including 'basalt' plugs; most common dikes = sub- } \\
\text { vertical to vertical, widths of } 50 \mathrm{~cm} \text { to } 2 \mathrm{~m} \text {, finely crystalline, non-vesicular to incipiently vesicular aphyric 'basalt' } \\
\text { bracketed by } 10-20 \mathrm{~cm} \text {-wide glassy or finer-grained margins } \\
\text { - Horizontal columnar jointing is well-developed in many of the wider vertical dikes } \\
\text { - Most dikes lack peperite margins \& are rarely straight: wavy, locally swirly shapes are the norm } \\
\text { - Sills are rare and thin }(<2 \mathrm{~m}) \text {, consisting of the same finely crystalline 'basalt' as most dikes* }\end{array}$ \\
\hline
\end{tabular}

* Ferrar Dolerite sills predominate over dikes in Convoy Range area, E of Coombs Hills (Pocknall et al., 1994) and in Olympus Range area, to the S (Isaac et al., 1996). Sills are also present in two arms of Allan Hills (Grapes et al., 1974). Large Ferrar Dolerite intrusions, some containing huge rafts (100s of $\mathrm{m}$ ) of Beacon Supergroup sandstone, crop out at Coombs Hills beyond the vent complex (Fig. 3) (see also Bradshaw, 1987; McClintock, 2001). 
Table 3

Calculation of the mass flow of basaltic magma in a cylindrical conduit based on the Wilson and Head (1981) model

\begin{tabular}{ccc}
\hline $\begin{array}{c}\text { Conduit radius } \\
(\mathrm{m})\end{array}$ & $\begin{array}{c}\text { Magma rise velocity } \\
(\mathrm{m} / \mathrm{s})^{*}\end{array}$ & $\begin{array}{c}\text { Mass eruption rate } \\
(\mathrm{kg} / \mathrm{s})\end{array}$ \\
\hline 1 & 0.8 & $7.2 \times 10^{3}$ \\
3 & 6.9 & $5.5 \times 10^{5}$ \\
10 & 38.5 & $3.4 \times 10^{7}$ \\
30 & 86.2 & $6.8 \times 10^{8}$ \\
\hline
\end{tabular}

* This is the vertical velocity that magma reaches in the conduit before the onset of volatile exsolution; as the buoyancy afforded by the crust-magma density differential is exactly compensated by friction on the conduit walls, this "rise velocity at depth" is constant. Assumes a magma viscosity of $300 \mathrm{~Pa} \mathrm{~s}$, plus densities of $2800 \mathrm{~kg} / \mathrm{m}^{3}$ for the magma $\& 3000 \mathrm{~kg} / \mathrm{m}^{3}$ for the crust.

Table 4

Observations and interpretations for the Kirkpatrick Basalt between the East Ridge and the summit of Mt Brooke at Coombs Hills, after Ross (2005)

\begin{tabular}{ll}
\hline \multicolumn{1}{c}{ Observations } & \multicolumn{1}{c}{ Interpretations } \\
\hline $\begin{array}{l}\text { Most lavas appear to be several 10s m-thick; columnar jointing is } \\
\text { variably developed \& phenocryst content + vesicularity also variable }\end{array}$ & Tabular-classic flow facies dominates? \\
$\begin{array}{l}\text { Vesicularity becomes higher in the upper } \sim 135 \mathrm{~m} \text {, with the } \\
\text { underlying lavas appearing relatively vesicle-poor }\end{array}$ & $\begin{array}{l}\text { Might represent an evolution from fire fountaining (efficient } \\
\text { degassing) to more passive effusion of lava (less efficient } \\
\text { degassing), but no specific evidence for fountaining such as } \\
\text { clastogenic lava or welded spatter (Head \& Wilson, 1989) was } \\
\text { observed }\end{array}$ \\
$\begin{array}{l}\text { No obvious entablatures (domains displaying more irregular } \\
\text { columns, including narrow radiating columns; Long \& Wood, 1986; } ;\end{array}$ & $\begin{array}{l}\text { Suggests a lack of water-controlled cooling for the flows sampled } \\
\text { Lyle, 2000) observed }- \text { only variably developed colonnades. In thin } \\
\text { section, oxide minerals are equant rather than feather-shaped or } \\
\text { dendritic }\end{array}$ \\
$\begin{array}{l}\text { Pillow lavas appear at the top of the section, on a pinnacle extending } \\
\text { above the summit arête. Locally, lenses of yellow-cream quartzose } \\
\text { sandstone, } \leq 1 \text { m-long \& } 20 \text { cm-thick, are intercalated }\end{array}$ & Temporary lake formed at this stage (late 'Kirkpatrick time') \\
\hline
\end{tabular}


Table 5

Observations and interpretations for cross-cutting zones of Beacon-rich lapilli-tuff (LTa at central Allan Hills, after Ross (2005) *

\begin{tabular}{|c|c|}
\hline Observations & Interpretations \\
\hline $\begin{array}{l}\text { - } \mathrm{LT}_{\mathrm{a}} \text { zones form clusters of oval to near-circular zones, each } 5-40 \mathrm{~m} \\
\text { across in map view } \\
\text { - These zones show sharp, steep to vertical contacts with enclosing } \mathrm{m}_{1} \\
\text { deposits (Fig. 7a) } \\
\text { - Field clast counts show that } \mathrm{LT}_{\mathrm{a}} \text { zones generally contain } 33-72 \% \text { (mean } \\
53 \% \text { ) lapilli-sized clasts (Fig. } 7 \mathrm{~b} \text { ). Apart from dearth of fragments } \\
>64 \mathrm{~mm} \text {, main difference relative to bulk of } \mathrm{m}_{1} \text { is presence of } 38-71 \% \\
\text { (mean } 55 \% \text { ) lapilli-sized, angular to subangular, greenish 'basaltic' clasts } \\
\text { (Fig. } 7 \mathrm{c} \text { ) } \\
\text { - Beacon Supergroup-derived lapilli are dominated by fine sandstone \& } \\
\text { siltstone, with subordinate amounts of coarse sandstone, medium } \\
\text { sandstone, carbonaceous mudstone \& coal } \\
\text { - The sharp, subvertical contacts between } \mathrm{LT}_{\mathrm{a}} \text { zones \& surrounding } \\
\text { breccias, plus the well-defined oval to sub-circular shapes of these zones, } \\
\text { are distinct from other structures observed within } \mathrm{m}_{1}\end{array}$ & $\begin{array}{l}\text { - Considering the high degree of } \\
\text { fragmentation \& dispersion indicated } \\
\text { by } \mathrm{m}_{1} \text { deposits, it is unlikely that } \mathrm{LT}_{\mathrm{a}} \\
\text { zones were transported unmodified } \\
\text { within the debris avalanche } \\
\text { - By analogy with Coombs Hills, it is } \\
\text { inferred that } \mathrm{LT}_{\mathrm{a}} \text { zones of central } \\
\text { Allan Hills are phreatomagmatic } \\
\text { deposits filling cross-cutting } \\
\text { structures formed during an episode } \\
\text { of Ferrar magmatism that postdates } \\
\text { deposition of } \mathrm{m}_{1}\end{array}$ \\
\hline
\end{tabular}

* These were referred to as "BX5" zones by Ross (2005)

Table 6

Field and petrographic characteristics of the Carapace Sandstone in the southeastern part of Carapace Nunatak, after Ross (2005)

Field observations

Petrographic observations (OU74526, 28, 29)

1. Best outcrop (locality 1 on Fig. 8) shows $\sim 35$ vertical metres of continuous section:

- in lower (northern) part, most beds are 5-20 cm-thick \& consist of beige to pale brown, fine to coarse sandstone (Fig. 9a) with minor conglomeratic horizons;

- in coarse sandstone beds, 'basaltic' clasts $1-5 \mathrm{~mm}$ in size are visible \& conglomeratic horizons contain rounded clasts of quartzitic sandstone $\leq 20 \mathrm{~cm}$ long;

- beds dominantly planar, with planar-parallel laminations, but local troughshaped cross-beds exist;

- in upper (southern) part of the outcrop, beds thin to $1 \mathrm{~cm}$ or less (Fig. 9b).

2. Numerous very small outcrops (locality 2 on Fig. 8), just below the first lava:

- mostly beige to pale brown, medium to coarse sandstone, locally with mud rip-up clasts;

- rare thin beds of fine sandstone or siltstone are seen; local conglomerate lenses contain Beacon sandstone clasts $\leq 10 \mathrm{~cm}$ long.
Overall (Fig. 9):

- all samples have similar components: detrital quartz 55-65\%; 'basaltic' clasts 10-20\%; Beacon clasts 7-10\%; detrital feldspar 0.5$5 \%$; zeolite cement 3-10\%; irresolvable material $1-5 \%$;

- trace micas \& hornblende but no silicic glass shards;

- 'basaltic' clasts: dense to incipiently vesicular*, formerly glassy (sideromelane?), lack crystals, now altered to clay \& palagonite; strongly resemble dominant type of clasts in Mawson at Coombs \& Allan Hills; likely formed as juvenile fragments.

\footnotetext{
* Vesicularity index of Houghton and Wilson (1989) throughout the paper.
} 
Table 7

Characteristics of Kirkpatrick lavas at Carapace Nunatak, after Ross (2005)

A. First lava, 15 m-thick, only visible on the southeast side of the nunatak:

- consists of black, dense, finely crystalline 'basalt';

- middle 2 m displays well-developed columnar joints, whereas rest has more irregular jointing patterns;

- petrographic texture typical of rapidly quenched tholeiitic lava with abundant glass, randomly oriented plagioclase laths ( $55 \%) \&$ very small opaque minerals (OU74530, Fig. 10c).

B. 40 m-thick sequence of pillow-palagonite breccia:

- on average, 10-20\% pillows or broken pillows "float" in matrix of hyaloclastite (angular fragments of black glassy 'basalt') \& palagonite, with $<5 \%$ cement (locally $\leq 20 \%$ ) (Fig. 10a);

- pillows in breccia have aspect ratios between 1:2 \& 1:10 (long axis horizontal or slightly inclined) \& chilled margins 0-4 cm thick (missing chilled margins explained by granulation \& entrainment of glassy fragments to form hyaloclastite);

- interior of pillows (OU74518, Fig. 10d) appears relatively unaltered \& resembles first lava petrographically;

- in NW windscoop (Fig. 8), base of breccia contains rafts of fossiliferous siltstone;

- in SE part of nunatak, pillows are more abundant \& two good exposures of pillow lava exist - pillows $\leq 3 \mathrm{~m}$ in horizontal dimension, with aspect ratios 1:1 to 1:4 (Fig. 10b); glassy rims $\sim 4 \mathrm{~cm}$ thick \& lacking vesicles; generally pillow interiors also lack vesicles however, large former gas cavities are found in pillow interiors (Fig. 10b, white spot in the central pillow); similar gas pockets are observed in certain types of degassed pahoehoe lavas in Hawaii (Swanson, 1973).

C. subaerial lavas between pillow-palagonite breccia \& mafic volcaniclastic interval:

- four lavas 8-50 $\mathrm{m}$ thick (total $>70 \mathrm{~m}$; Bradshaw, 1987), dipping $\sim 15^{\circ}$ westward;

- texture varies from dense, medium-grained (OU74520) to finely crystalline with $10 \%$ vesicles.

D. subaerial lavas above mafic volcaniclastic interval:

- $~ 100 \mathrm{~m}$ of lavas above volcaniclastic horizons, but repetition by faulting possible (exposures discontinuous);

- in OU74423 \& 74433, textures indicate slower cooling than first lava \& pillow interiors: larger, equant opaques, somewhat less glass \& more pyroxene phenocrysts, zoned plagioclase (e.g., Fig. 10e). 
Table 8

Characteristics of the volcaniclastic intervals in the Kirkpatrick sequence at Carapace Nunatak, after Ross (2005)

A. Northern outcrop (Fig. 8, locality 3):

- $~ 40 \mathrm{~m}$ lower than the southern outcrop due to faulting;

- dominated by beige to pale-brown coarse tuffs \& fine lapilli-tuffs, displaying rare accretionary lapilli (a.l.) $\leq 2 \mathrm{~cm}$ across (OU74524, Fig. 11a);

- in middle of outcrop, area $<1 \mathrm{~m}^{2}$ topographically depressed by a few dm relative to surrounding rocks shows much greater concentration of a.l. (sample OU74525) - probably represents window onto thin bed rich in a.l.;

- apart from a.l., main components are detrital quartz \& dense to incipiently vesicular, formerly glassy 'basaltic' shards; a few clasts of vesicular 'basalt' also visible (Fig. 11c); rare Beacon clasts include coal \& mudstone;

- unusual amount of crystalline 'basalt' clasts (Figs. 11b, 11d) compared to Mawson deposits at Coombs \& Allan Hills.

\section{B. Southern outcrop (Figure 8, locality 4):}

- shows two distinct volcaniclastic intervals separated by a thin lava flow (described by Bradshaw as "slaggy" \& "highly vesicular", but contains only $10-20 \%$ vesicles 5-15 mm across);

- lower volcaniclastic sequence $\sim 10 \mathrm{~m}$-thick, starts with $<1 \mathrm{~m}$ fine tuff, followed by sub-equal thicknesses of: (a) coarse tuff with glassy 'basaltic' fragments 2-5 mm across (OU74522); (b) fine tuff with rare a.1. $\leq 2 \mathrm{~mm}$ (OU74521), the upper part shows planar-parallel lamination;

- upper volcaniclastic sequence is $<10 \mathrm{~m}$-thick in total; starts with $75 \mathrm{~cm}$ of fine tuff, followed by $5-6 \mathrm{~m}$ of coarse tuff \& $2 \mathrm{~m}$ of fine tuff;

- no cross-lamination or cross-bedding observed.

Table 9

Location and field description of geochemical samples (after Ross, 2005) *

OU \# Location Field description

73160 Coombs Hills Thin 'basalt' sill (a few metres thick), medium- to fine-grained centre, invading the Mawson Formation

73163 Coombs Hills From fragment $(30$ x $40 \mathrm{~cm})$ of "dolerite", grain-size 1-3 mm, not foliated, in a Beacon-rich lapilli-tuff cross-cutting zone, south of Pyramid

73251 Coombs Hills Kirkpatrick lava, Mt Brooke, dense, finely crystalline

73260 Coombs Hills Centre of relatively large 'basalt' plug, dense, finely crystalline, invading Mawson Fm.

74492 Allan Hills Block of finely crystalline 'basalt' in a cross-cutting 'basalt'-rich tuff-breccia or lapilli-tuff body

74494 Allan Hills 'Basalt' plug 75 x 75 m across in Feistmantel Valley, invading grey breccias from Mawson $\mathrm{m}_{1}$

74518 Carapace N. Pillow-palagonite breccia: pillow interior (Kirkpatrick Basalt)

74523 Carapace N. Kirkpatrick Basalt, dense lava (above the pillow-palagonite breccias)

74530 Carapace N. Kirkpatrick Basalt, first lava (dense, columnar-jointed, finely crystalline, below pillowpalagonite breccias)

74533 Carapace N. Lava near summit, dense to incipiently vesicular, medium-grained

* Methods: only least altered samples selected in the field, with no visible vesicle fillings; petrographic examination confirmed that mineralogic alteration was low; rock chips crushed into fine powder in tungsten swing mill; XRF apparatus used at University of Otago was Philips PW2400 spectrometer calibrated with international standards; lower detection limits 5-20 ppm for major elements \& typically $<5$ ppm for trace elements. 
Table 10

Geochemical results for ten new Ferrar samples (not recalculated on a volatile-free basis; after Ross, 2005) ${ }^{(1)}$

\begin{tabular}{|c|c|c|c|c|c|c|c|c|c|c|}
\hline & \multicolumn{4}{|c|}{ Coombs Hills } & \multicolumn{2}{|c|}{ Allan Hills } & \multicolumn{4}{|c|}{ Carapace Nunatak } \\
\hline & $\begin{array}{c}73160 \\
\text { Sill }\end{array}$ & $\begin{array}{c}73163 \\
\text { 'dolerite' } \\
\text { block }^{(2)}\end{array}$ & $\begin{array}{c}73251 \\
\text { lava }\end{array}$ & $\begin{array}{c}73260 \\
\text { plug }\end{array}$ & $\begin{array}{l}74492 \\
\text { 'basalt' } \\
\text { block }\end{array}$ & $\begin{array}{c}74494 \\
\text { plug }\end{array}$ & $\begin{array}{l}74518 \\
\text { pillow } \\
\text { interior }\end{array}$ & $\begin{array}{c}74523 \\
\text { lava }\end{array}$ & $\begin{array}{c}74530 \\
\text { lava }\end{array}$ & $\begin{array}{c}74533 \\
\text { lava }\end{array}$ \\
\hline $\mathrm{SiO}_{2}$ & 52.26 & 64.10 & 57.39 & 53.84 & 52.84 & 54.43 & 55.45 & 55.84 & 56.96 & 54.50 \\
\hline $\mathrm{TiO}_{2}$ & 0.64 & 1.13 & 0.99 & 0.62 & 0.62 & 0.62 & 1.00 & 0.91 & 0.98 & 0.57 \\
\hline $\mathrm{Al}_{2} \mathrm{O}_{3}$ & 15.52 & 11.25 & 13.37 & 14.63 & 14.78 & 14.79 & 13.49 & 13.97 & 13.45 & 13.92 \\
\hline $\mathrm{Fe}_{2} \mathrm{O}_{3}{ }^{\mathrm{T}}$ & 9.93 & 11.34 & 12.49 & 9.88 & 9.92 & 9.89 & 12.59 & 11.81 & 12.50 & 9.82 \\
\hline $\mathrm{MnO}$ & 0.17 & 0.14 & 0.19 & 0.17 & 0.17 & 0.17 & 0.20 & 0.19 & 0.19 & 0.17 \\
\hline $\mathrm{MgO}$ & 6.31 & 0.82 & 3.95 & 6.72 & 6.88 & 6.81 & 4.11 & 5.03 & 4.00 & 8.44 \\
\hline $\mathrm{CaO}$ & 10.89 & 3.96 & 8.55 & 10.70 & 10.13 & 10.89 & 8.89 & 9.48 & 8.63 & 10.84 \\
\hline $\mathrm{Na}_{2} \mathrm{O}$ & 2.26 & 2.30 & 2.12 & 1.77 & 1.90 & 1.74 & 2.26 & 1.96 & 2.30 & 1.56 \\
\hline $\mathrm{K}_{2} \mathrm{O}$ & 0.57 & 3.12 & 1.22 & 0.84 & 1.21 & 0.63 & 0.99 & 1.05 & 0.87 & 0.71 \\
\hline $\mathrm{P}_{2} \mathrm{O}_{5}$ & 0.09 & 0.32 & 0.14 & 0.09 & 0.09 & 0.09 & 0.14 & 0.12 & 0.14 & 0.08 \\
\hline LOI & 1.75 & 1.68 & 0.10 & 1.63 & 1.96 & 0.44 & 0.79 & 0.43 & 0.33 & 0.11 \\
\hline Total & 100.39 & 100.16 & 100.51 & 100.89 & 100.50 & 100.50 & 99.91 & 100.79 & 100.35 & 100.72 \\
\hline $\mathrm{FeO}^{\mathrm{T}}$ & 8.94 & 10.21 & 11.24 & 8.89 & 8.93 & 8.90 & 11.33 & 10.63 & 11.25 & 8.84 \\
\hline $\mathrm{Mg} \#$ & 41.39 & 7.44 & 26.00 & 43.04 & 43.52 & 43.35 & 26.62 & 32.12 & 26.23 & 48.85 \\
\hline $\mathrm{Sc}$ & 39 & 15 & 41 & 37 & 42 & 40 & 45 & 39 & 43 & 39 \\
\hline $\mathrm{V}$ & 215 & 13 & 304 & 218 & 235 & 226 & 315 & 260 & 308 & 217 \\
\hline $\mathrm{Cr}$ & 107 & bd & 20 & 121 & 149 & 137 & 19 & 35 & 21 & 196 \\
\hline $\mathrm{Ni}$ & 70 & 4 & 26 & 73 & 78 & 77 & 32 & 40 & 31 & 87 \\
\hline $\mathrm{Cu}$ & 82 & 26 & 96 & 76 & 82 & 84 & 113 & 119 & 108 & 70 \\
\hline $\mathrm{Zn}$ & 76 & 105 & 91 & 69 & 75 & 76 & 99 & 87 & 99 & 71 \\
\hline $\mathrm{Ga}$ & 15 & 22 & 17 & 16 & 14 & 15 & 17 & 17 & 17 & 15 \\
\hline As & 3 & 2 & 2 & 3 & 1 & 2 & 2 & 2 & 2 & 1 \\
\hline $\mathrm{Rb}$ & 25 & 107 & 49 & 33 & 43 & 28 & 40 & 43 & 45 & 25 \\
\hline $\mathrm{Sr}$ & 118 & 84 & 143 & 111 & 93 & 131 & 135 & 136 & 137 & 115 \\
\hline $\mathrm{Y}$ & 22 & 56 & 29 & 21 & 23 & 24 & 30 & 27 & 29 & 19 \\
\hline $\mathrm{Zr}$ & 102 & 316 & 153 & 99 & 101 & 99 & 153 & 133 & 151 & 88 \\
\hline $\mathrm{Nb}$ & 2 & 8 & 5 & 1 & 2 & 2 & 3 & 4 & 4 & 2 \\
\hline $\mathrm{Ba}$ & 138 & 649 & 329 & 202 & 212 & 193 & 210 & 296 & 268 & 185 \\
\hline $\mathrm{La}$ & 13 & 53 & 22 & 19 & 16 & 19 & 26 & 19 & 26 & 10 \\
\hline $\mathrm{Ce}$ & 32 & 99 & 44 & 15 & 20 & 10 & 28 & 31 & 29 & 20 \\
\hline $\mathrm{Nd}$ & 16 & 55 & 28 & 14 & 18 & 17 & 21 & 24 & 24 & 16 \\
\hline $\mathrm{Pb}$ & 3 & 18 & 8 & 4 & 5 & 5 & 8 & 7 & 8 & 4 \\
\hline Th & 3 & 11 & 6 & 2 & 1 & 2 & 3 & 4 & 5 & 2 \\
\hline $\mathrm{U}$ & 1 & 6 & 4 & 1 & 1 & 1 & 4 & 4 & 4 & 1 \\
\hline
\end{tabular}

(1) Major elements (in wt \%) and trace elements (in ppm) by XRF, Geology Department, Otago University (Damian Walls, analyst). In the raw data, all iron is expressed as $\mathrm{Fe}_{2} \mathrm{O}_{3}$; this was converted to $\mathrm{FeO}^{\mathrm{T}}$ using a 0.9 multiplication factor. $\mathrm{Mg \#}$ is the ratio $\mathrm{MgO} /\left(\mathrm{MgO}+\mathrm{FeO}^{\mathrm{T}}\right)$. Niobium values are suspiciously low, probably due to analytical error, relative to previously published analyses of the MFCT magma type (4-11 ppm depending on the Mg\#; data sources in the caption of Fig. 12). See table 9 for sample descriptions.

(2) This sample plots well outside the field defined by MFCT lavas and Ferrar sills on some diagrams (Figs. 12 \& 13); it was taken from a 'dolerite' block at Coombs Hills (Table 9). This sample has significantly higher amounts of $\mathrm{Ba}, \mathrm{Ga}, \mathrm{K}_{2} \mathrm{O}, \mathrm{Nb}, \mathrm{P}_{2} \mathrm{O}_{5}, \mathrm{~Pb}, \mathrm{Rb}, \mathrm{SiO}_{2}, \mathrm{U}$, Th, $\mathrm{Y}$, $\mathrm{Zn}$, $\mathrm{Zr}$, and light rare earth elements than all the others analysed, with significantly lower amounts of $\mathrm{Al}_{2} \mathrm{O}_{3}, \mathrm{CaO}, \mathrm{Cr}, \mathrm{Cu}, \mathrm{MgO}, \mathrm{Ni}, \mathrm{Sc}, \mathrm{Sr}$, and $\mathrm{V}$. Other oxides such as TiO 2 and $\mathrm{FeO}^{\mathrm{T}}$ are within the range of MFCT compositions. OU73163 plots as a "dacite" on discrimination diagrams (Fig. 13). On several variation diagrams (Y, alkalis or $\mathrm{Rb}$ vs. Mg\#), the sample plots in the upper left corner, in the continuation of the $\mathrm{MFCT}$ trend. The same feature is visible on the $\mathrm{TiO}_{2}$ vs. $\mathrm{Mg \#}$ diagram and petrographic examination shows a strong consertal to granophyric texture, with $\mathrm{An}_{48}$ plagioclase. It is concluded that the analysed fragment was derived from a Jurassic magma belonging to the Ferrar province. 


\section{Figures}

1. (a) Map showing the distribution of the Beacon Supergroup, Ferrar Dolerite, and Kirkpatrick Basalt in the Transantarctic Mountains (TAM). Mafic volcaniclastic deposits, including the Mawson Formation, are found underlying the Kirkpatrick Basalt in North Victoria Land (NVL), South Victoria Land (SVL) and the Central Transantarctic Mountains (CTM). Modified from Hanson and Elliot (1996). (b) Hypothetical former distribution of the Mawson Formation (including the Carapace Sandstone at the nunatak of the same name). The illustrated belt is $195 \mathrm{~km}$ long, with a mean width of $21 \mathrm{~km}$. Exposed thicknesses of mafic volcaniclastics are generally over $60 \mathrm{~m}$. Base map modified from Stump (1995).

2. Summary of Beacon Supergroup stratigraphy in South Victoria Land (SVL), using information from Barrett and Kohn (1975); Barrett (1991); Bradshaw (1991); and other sources cited by McClintock (2001). CTM = Central Transantarctic Mountains. Local thickness (Allan Hills) of uppermost Beacon Supergroup in bracketed italics.

3. Geologic map of Coombs Hills, modified from McClintock (2001). Thin dashed lines are $200 \mathrm{~m}$ contours. Numbered stars denote locations discussed in the text: (1) the 'basalt' plug shown in figure 4; and (2) the East Ridge tuff ring. Sections 96-48 and 96-49 were studied by Elliot (2000) and Elliot and Hanson (2001); 96-49 displays $370 \mathrm{~m}$ of unbedded coarse volcaniclastic rocks overlain by $22 \mathrm{~m}$ of poorly exposed layered rocks, whereas the Mawson at 96-48 is under $200 \mathrm{~m}$-thick (base not exposed) and consists of finer-grained layers.

4. 'Basalt' plug cut by volcaniclastic dike on the West Ridge of Coombs Hills (location 1 on Fig. 3). (a) Pace and compass map; (b) interpretative section X-X'; (c) photo of the plug (marked by a dashed line) looking southward, with Mt Brooke in the background; (d) view of the plug's interior, showing preferentially eroded volcaniclastic dike cutting the plug. For facies codes $\left(\mathrm{LT}_{\mathrm{h}}, \mathrm{TB}_{\mathrm{j}}\right)$ see Table 1 .

5. Geological map and cross-sections of southern Allan Hills, modified from Ross (2005) and Ross and White (2005c). Bold lines marked AH-1 to AH-4 indicate prominent block-rich layers. LT = lapilli-tuff; TB = tuff-breccia.

6. Geological map and vertical sections for central Allan Hills, modified from Ross (2005) and Reubi et al. (2005). "TB $\mathrm{j}_{\mathrm{j}}$ on section B-B' stands for poorly sorted, 'basalt'-rich tuff-breccia zones cross-cutting $\mathrm{m}_{1}$.

7. Features of poorly sorted, Beacon-rich lapilli-tuff $\left(\mathrm{LT}_{\mathrm{a}}\right)$ zones invading the $\mathrm{m}_{1}$ member of the Mawson Formation in central Allan Hills. (a) View of the abrupt, steep to vertical contact (dashed line) between a $\mathrm{LT}_{\mathrm{a}}$ zone and host $\mathrm{m}_{1}$. Hammer for scale. (b) Summary of ten field clast counts from $\mathrm{LT}_{\mathrm{a}}$ zones in Feistmantel Valley, after Ross (2005). (c) A fragment of incipiently to poorly vesicular 'basalt' (arrow) in a $\mathrm{LT}_{\mathrm{a}}$ zone (photo courtesy of O. Reubi).

8. Aerial photograph of Carapace Nunatak with superimposed longitude/latitude grid and geology. The grid appears slightly tilted because of the imperfect photo registration, based on six GPS points. There is also some distortion in the western margin of the photograph, as shown by the bold arrow, the two ends of which correspond to the same geographical point. See also the geological map by Bradshaw (1987). Numbers on the map correspond to localities discussed in the text: (1) \& (2) outcrops of Carapace Sandstone; (3) \& (4) volcaniclastic intervals in the Kirkpatrick sequence.

9. Plane-polarized, transmitted light photomicrographs of Carapace Sandstone samples: (a) OU74526, from the lower part of the formation; (b) OU74528, from the middle part. Constituents: B, dense, formerly glassy 'basalt' (now altered to clays and palagonite); FG, altered, fine-grained sedimentary? rock; Mi, mica; $\mathbf{Q}$, quartz; $\mathbf{Z}$, zeolite cement. Circles on (b) due to glue bubbles.

10. Kirkpatrick lavas at Carapace Nunatak. (a) Pillow-palagonite breccias showing dismembered 'basalt' pillows "floating" in hyaloclastite (angular fragments of black glassy 'basalt') with abundant palagonite (orange in outcrop, grey on the photo) and sparse white cement. (b) Local pillow lavas. Ice axe handle is $70 \mathrm{~cm}$ long. (c) Photomicrograph of the first lava, showing the intersertal texture. (d) Photomicrograph of a pillow interior, showing the glomeroporphyritic texture. (e) Photomicrograph of a lava above the volcaniclastic interval, with an intersertal to intergranular texture. Last three images in plane-polarized transmitted light. Note the scale change between (c)-(d) and (e), making the crystal size much smaller in (c)-(d). Abbreviations: AG, altered glass, $\mathbf{C P X}$, clinopyroxene; $\mathbf{G}$, fresh glass or tachylite; $\mathbf{O}$, opaque minerals; $\mathbf{P}$, plagioclase.

11. Plane-polarized, transmitted light photomicrographs of fine lapilli-tuffs and coarse tuffs containing accretionary lapilli (a.l.) in the volcaniclastic intervals of the Kirkpatrick sequence at Carapace Nunatak: (a)-(c), sample OU74524; (d), sample OU74525. Overall, the most common constituents in these rocks are formerly glassy 'basalt', either dense or vesicular (Bd, 
Bv) and quartz (Q) (the photos do not show this), but crystalline 'basalt' clasts (Bc) are more frequent than in all Mawson samples; OPX, orthopyroxene. Note different scale for (b).

12. Variation diagrams for selected major and trace elements versus Mg-number. Major elements were recalculated to $100 \%$ on a volatile-free basis for these plots. The bold lozenges represent the samples listed in Tables 9 and 10. Grey symbols are published analyses for the Kirkpatrick Basalt (MFCT, SPCT: see text) and Ferrar Dolerite sills, throughout the Transantarctic Mountains, after Elliot (1972), Mensing et al. (1984), Siders and Elliot (1985), Ford and Kistler (1980), Hergt et al. (1989), Fleming et al. (1992, 1995), Wihelm and Worner (1996), Antonini et al. (1999), Elliot et al. (1999), Demarchi et al. (2001) and P.R. Kyle, pers. commun. (2003) [major and trace element data for MFCT flows at Gorgon Peak, Prince Albert Mountains, referred to in Kyle et al., 1983]. Sample OU73163 is discussed in a footnote of Table 10.

13. Geochemical discrimination diagrams: (a) alkalis versus silica after Le Maitre (1989); (b) silica versus $\mathrm{Zr} / \mathrm{TiO}{ }_{2}$ after Winchester and Floyd (1977); (c) tholeiitic versus calc-alkaline after Irvine and Baragar (1971). Relevant fields for (a) are B: basalt, O1: basaltic andesite, O2: andesite, O3: dacite. Symbols and sources of data as in figure 12; sample OU73163 is discussed in a footnote of Table 10 .

14. Geological and geomorphological evolution of the Coombs-Allan Hills area from the Permian to the early Jurassic. Thickness of rock units is schematic only. Cartoons (a) to (b) show a slight tilt of the strata to the northwest because of the overall direction of stream flow during deposition of the Victoria Group. This tilt is removed arbitrarily in (c) (could have occurred earlier) because of the debris avalanche flowing northeastward (also, there is stream flow to the NE in d). The limit of the topographic depression for the Allan Hills area in (c) and subsequent cartoons is speculative, except for the northeast end: the Lashly Formation is still exposed in the Roscollyn Tor area, marked by a 'X'. The emplacement of sills is not shown. See text for discussion. 
a

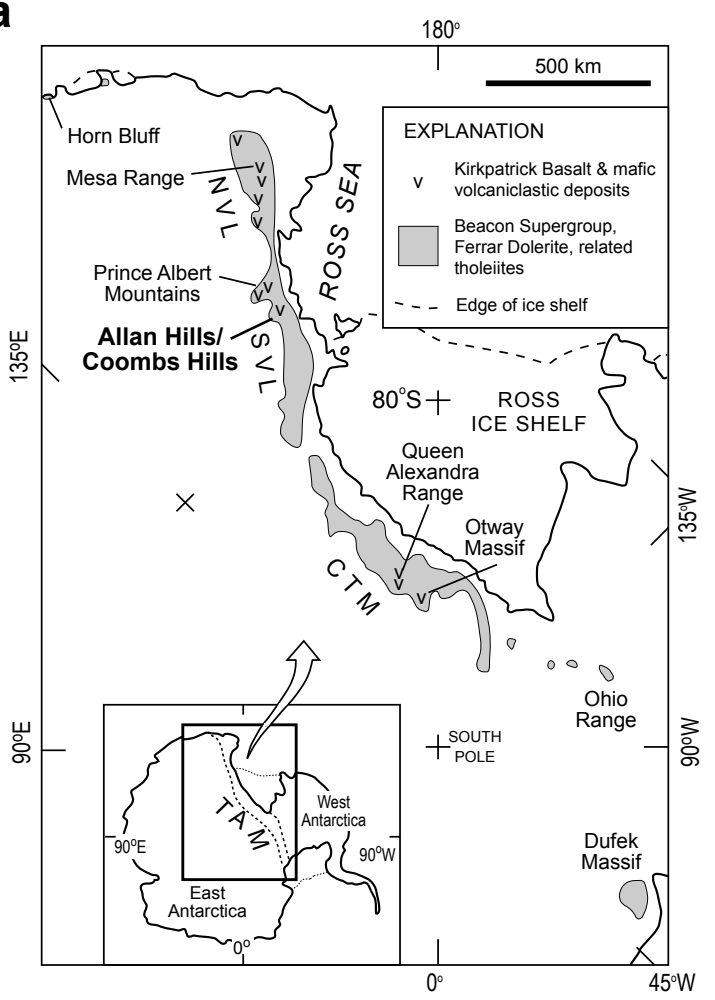

b Hypoth. former distribution of Mawson Fm

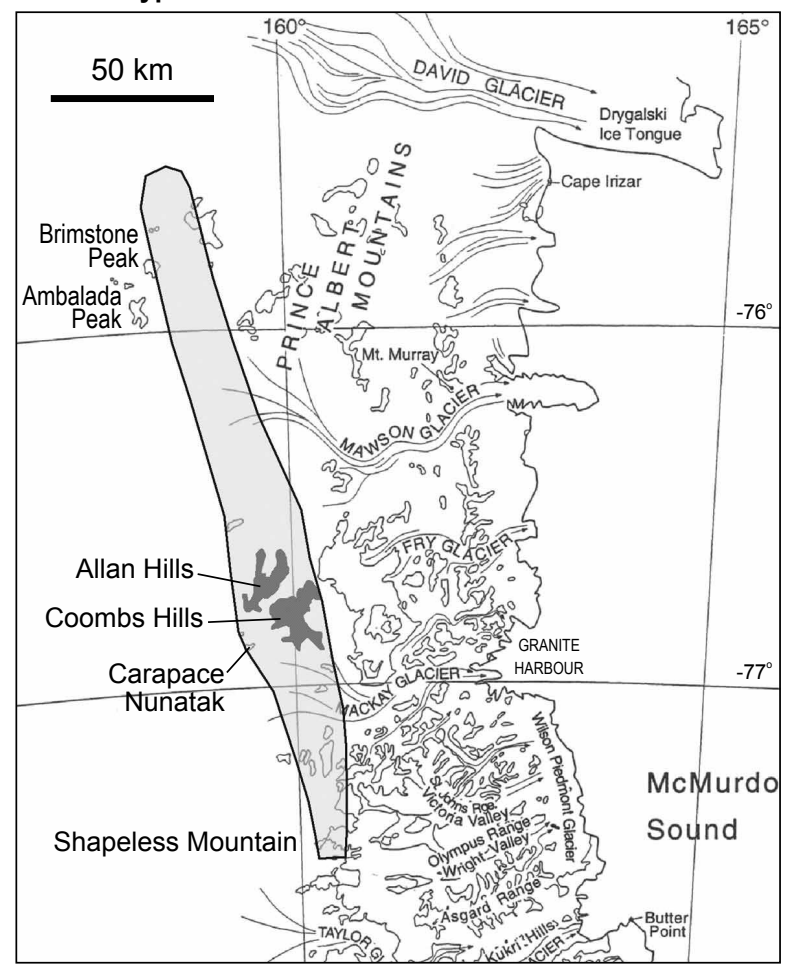

ROSS ET AL., SPECIAL ISSUE, FIG. 1 


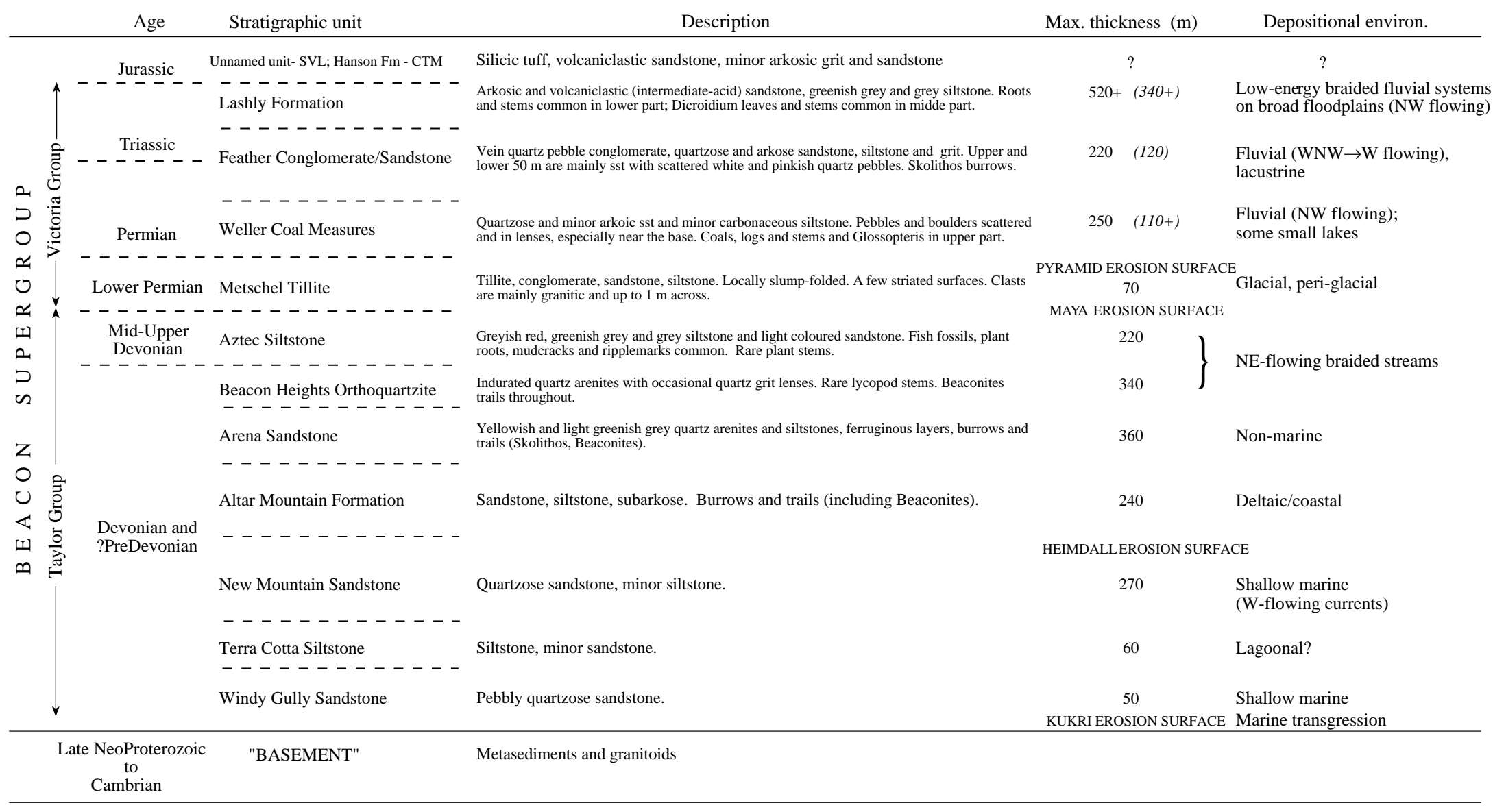

ROSS ET AL., SPECIAL ISSUE, FIG. 2 


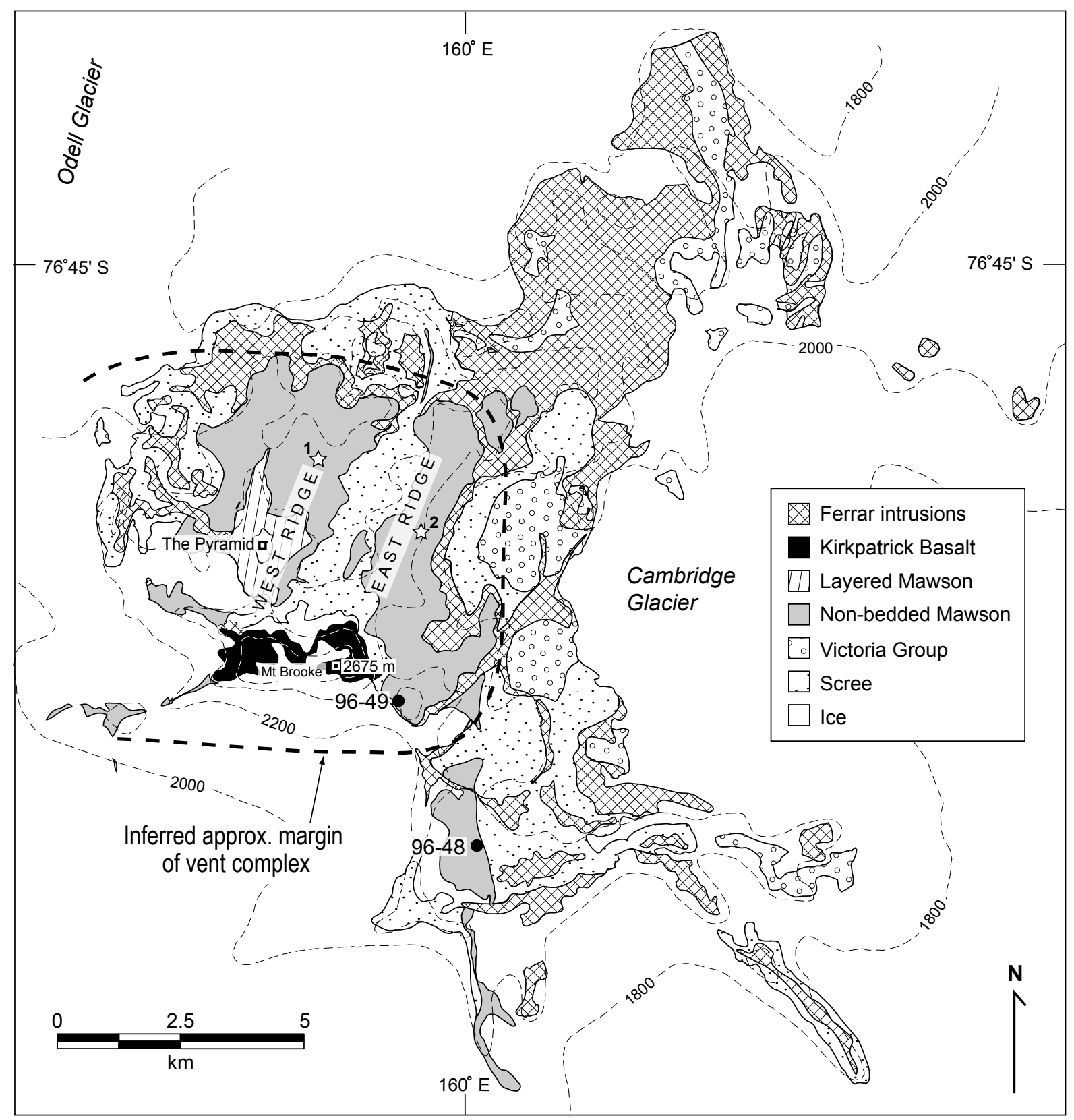

ROSS ET AL., SPECIAL ISSUE, FIG. 3 

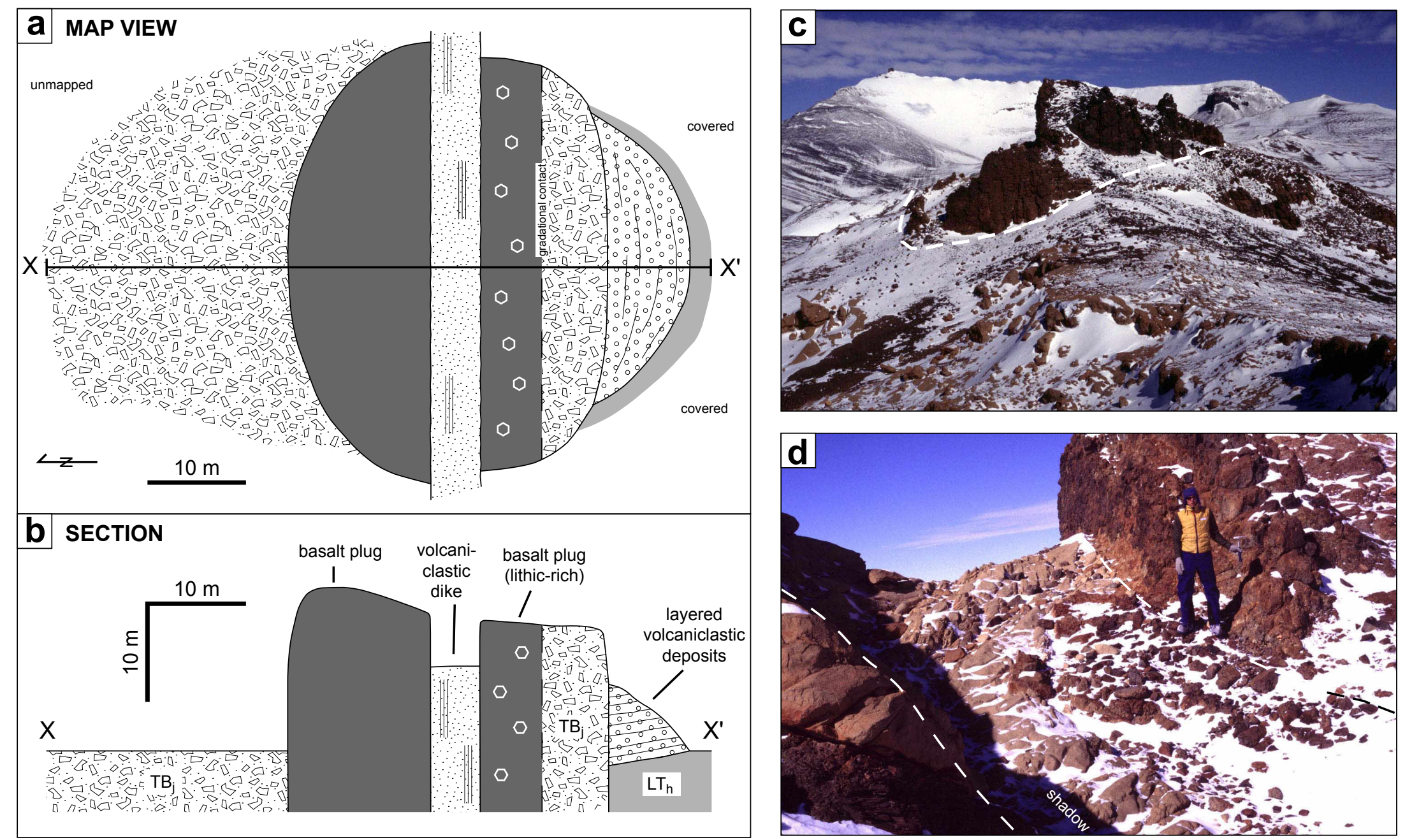

ROSS ET AL., SPECIAL ISSUE, FIG. 4 


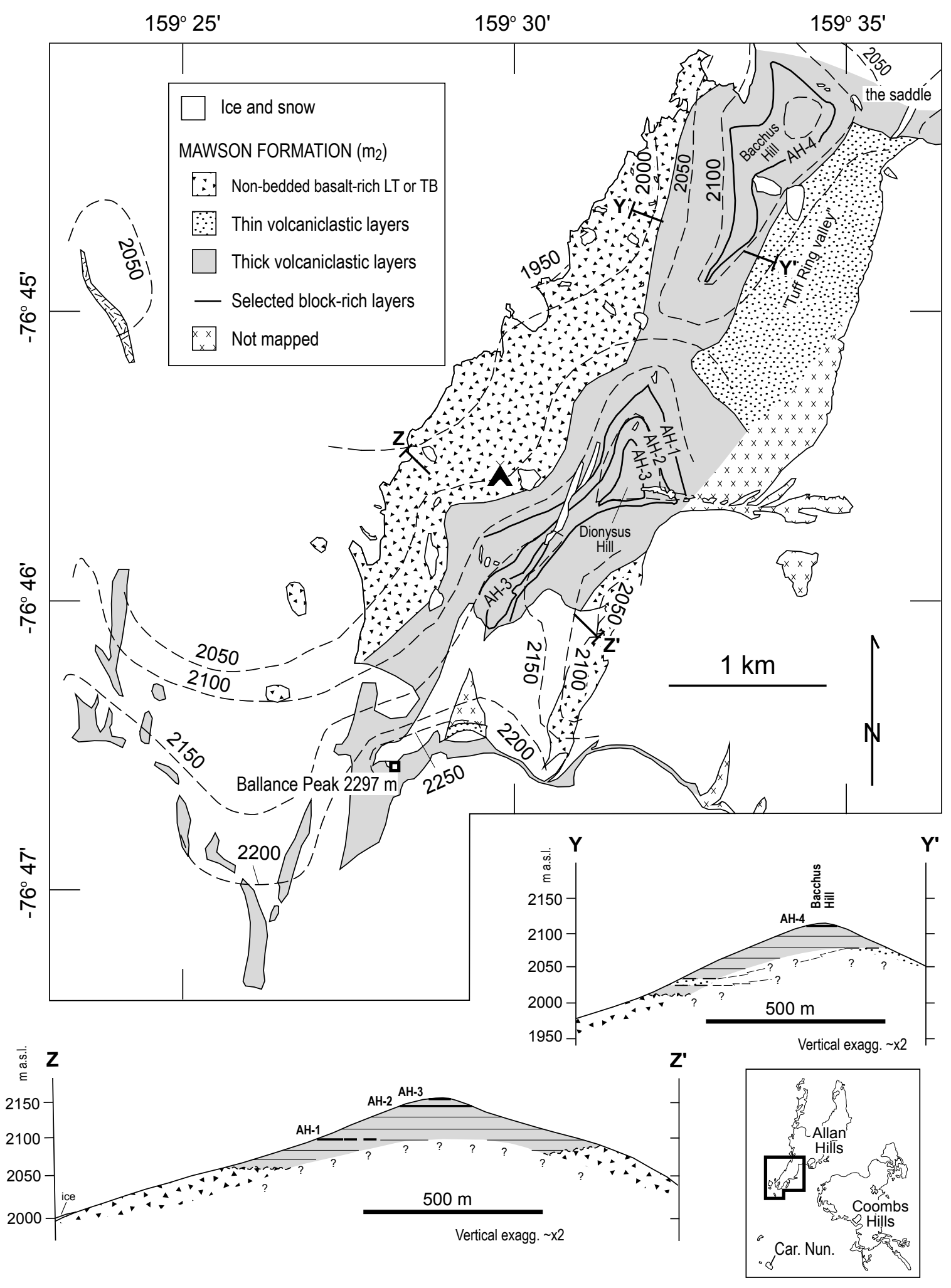

ROSS ET AL., SPECIAL ISSUE, FIG. 5 

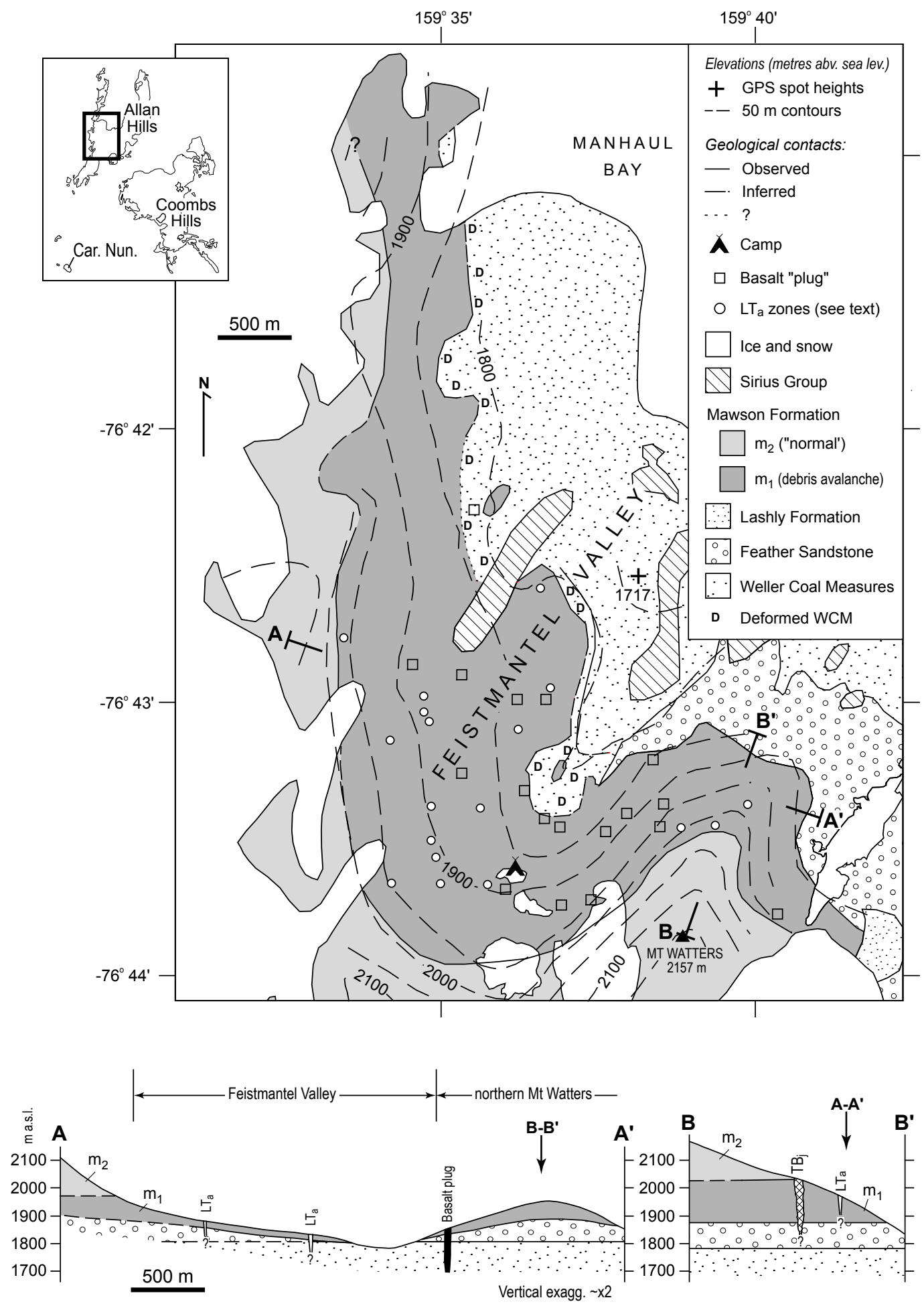

ROSS ET AL., SPECIAL ISSUE, FIG. 6 

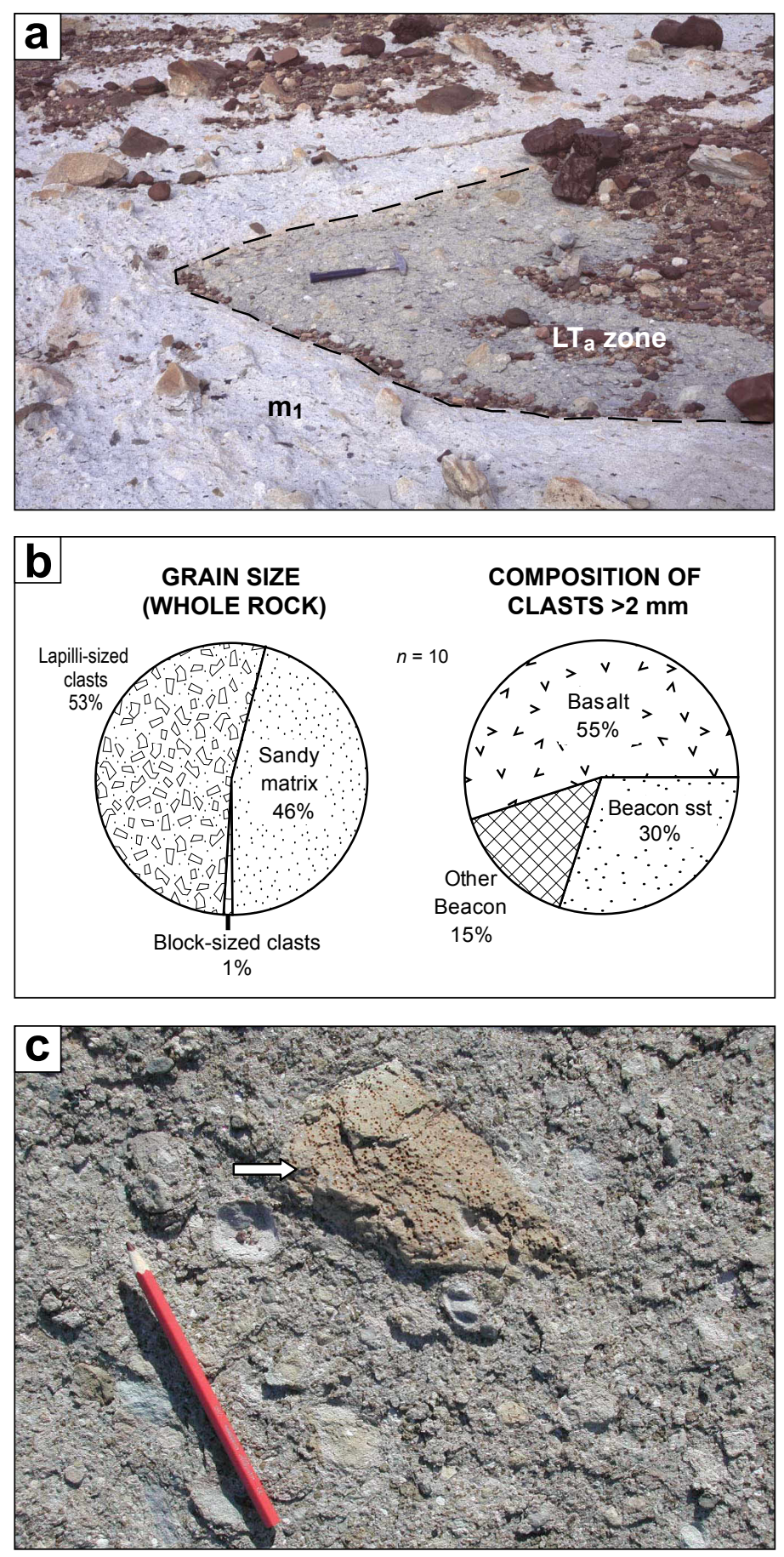

ROSS ET AL., SPECIAL ISSUE, FIG. 7 


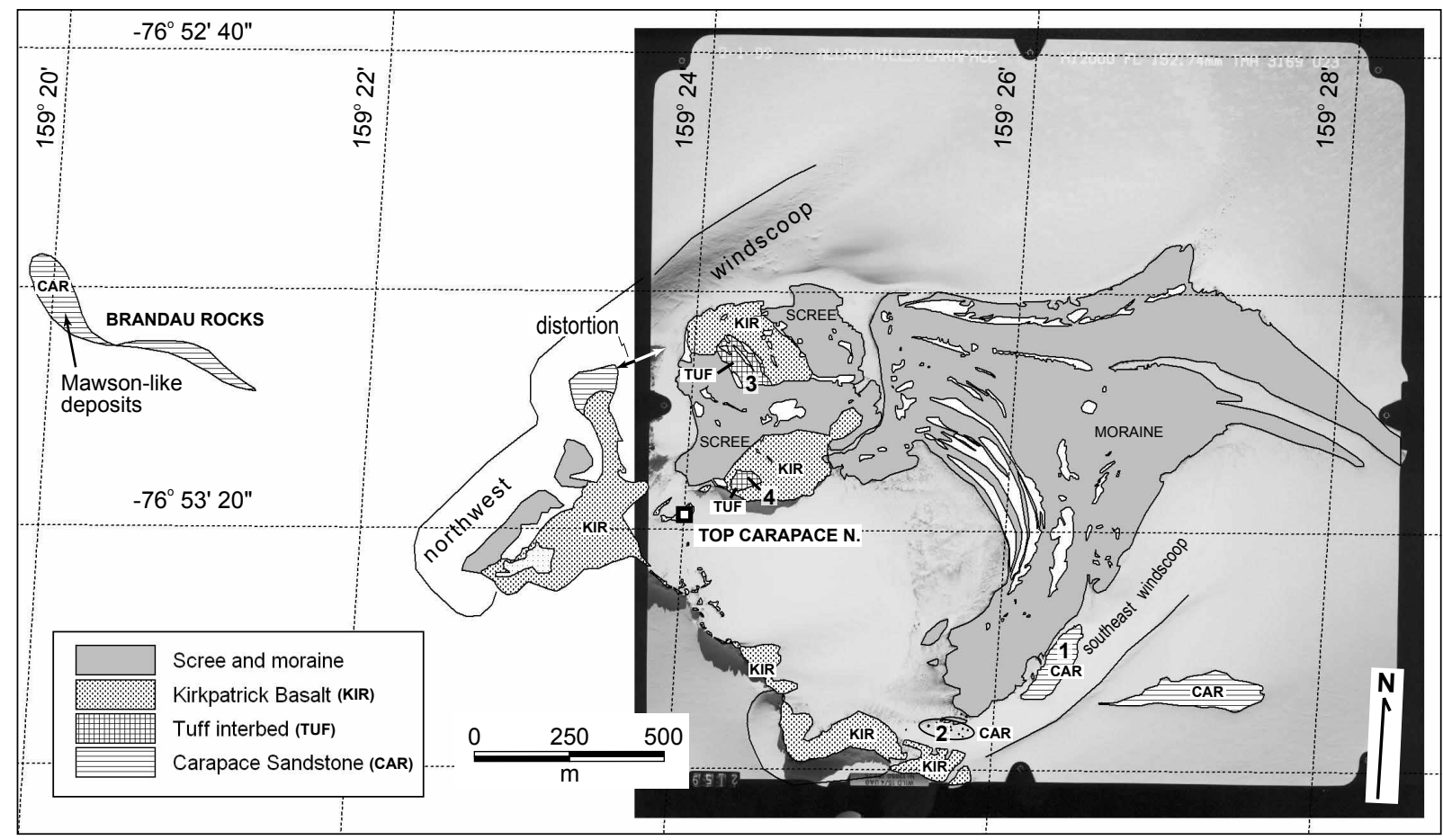

ROSS ET AL., SPECIAL ISSUE, FIG. 8 

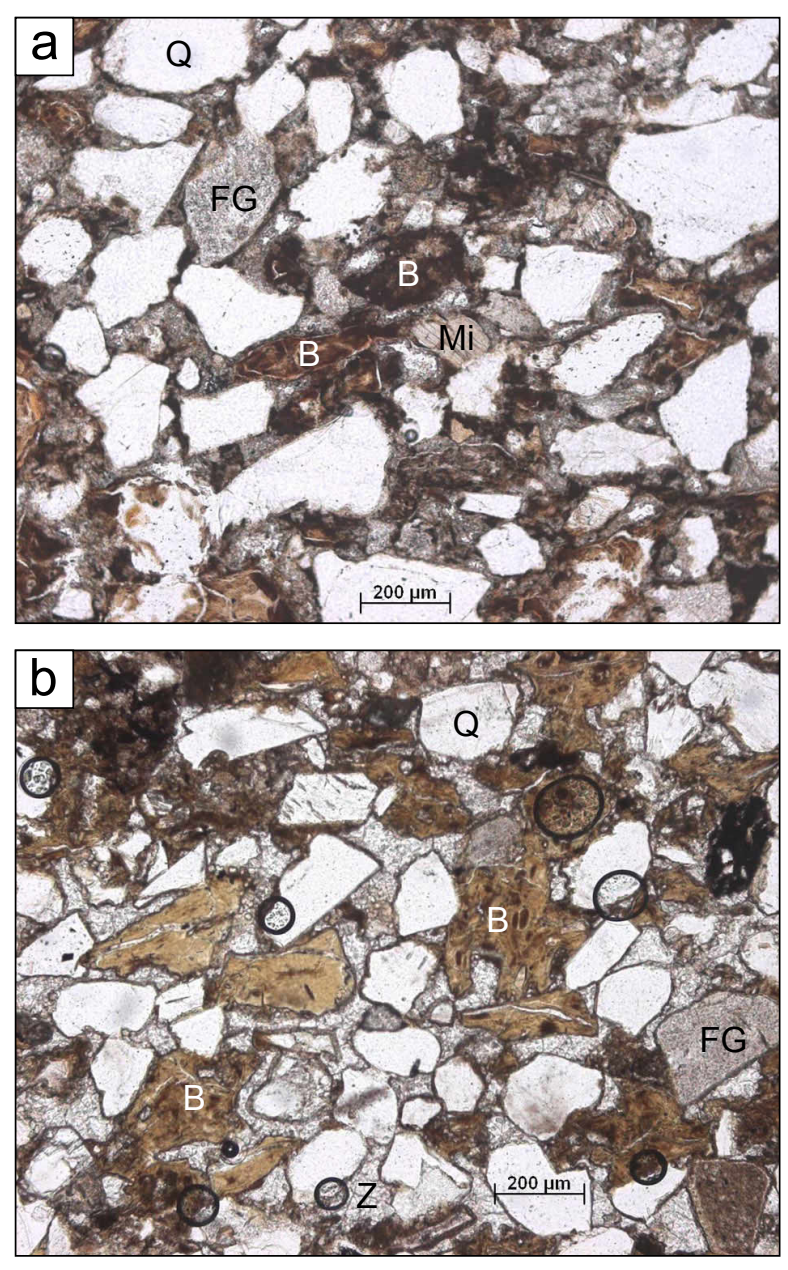

ROSS ET AL., SPECIAL ISSUE, FIG. 9 

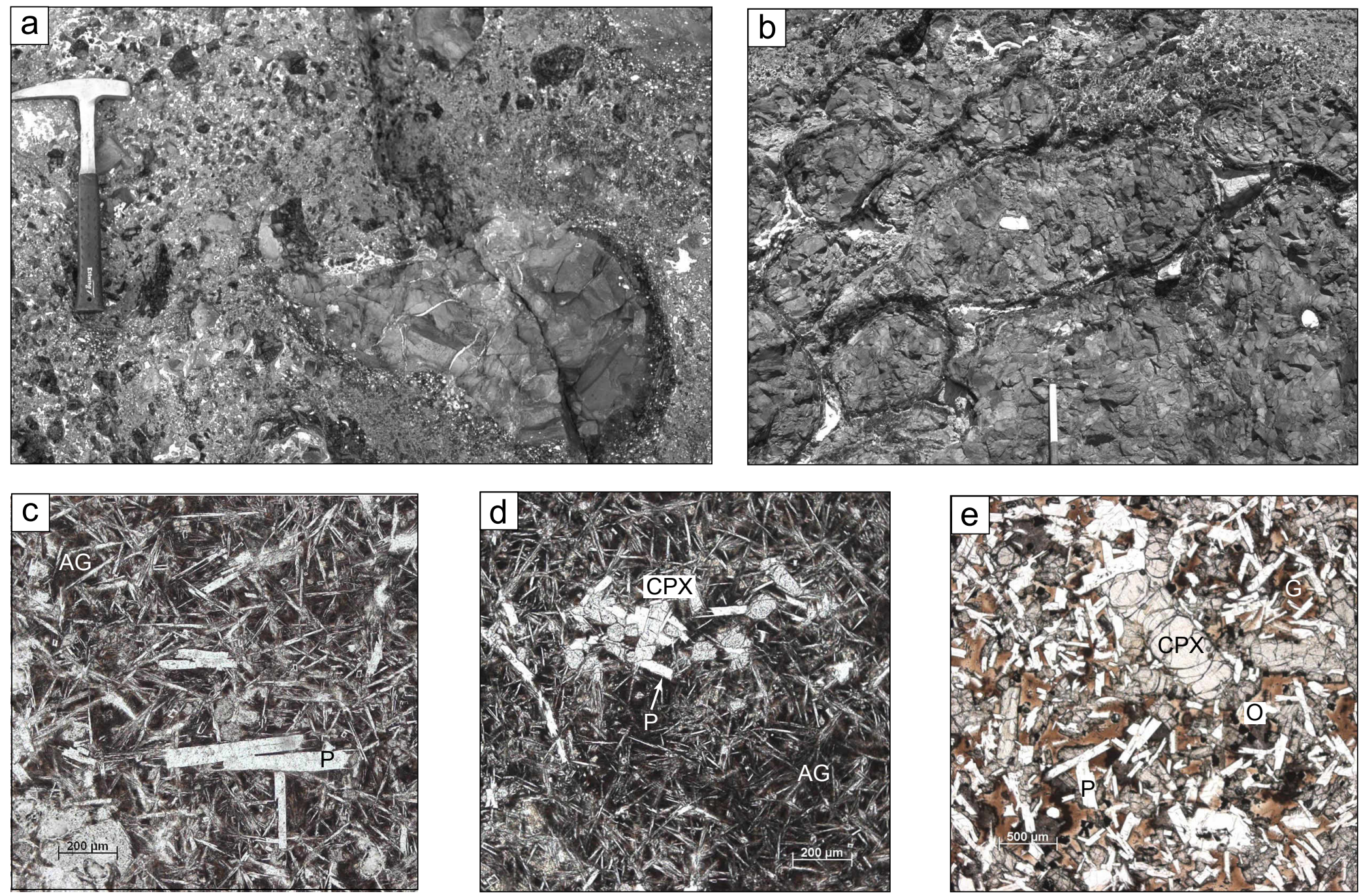

ROSS ET AL., SPECIAL ISSUE, FIG. 10 

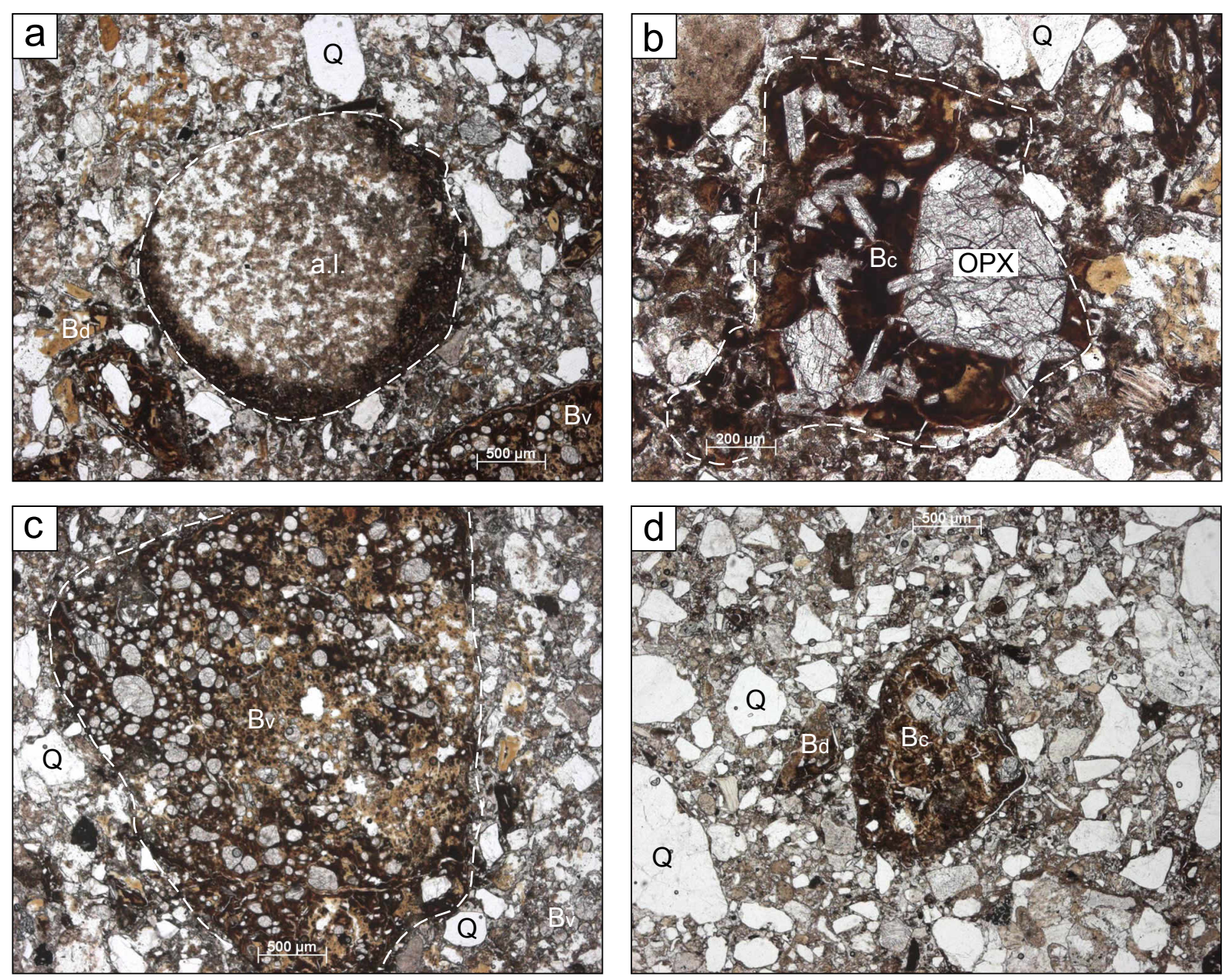

ROSS ET AL., SPECIAL ISSUE, FIG. 11 

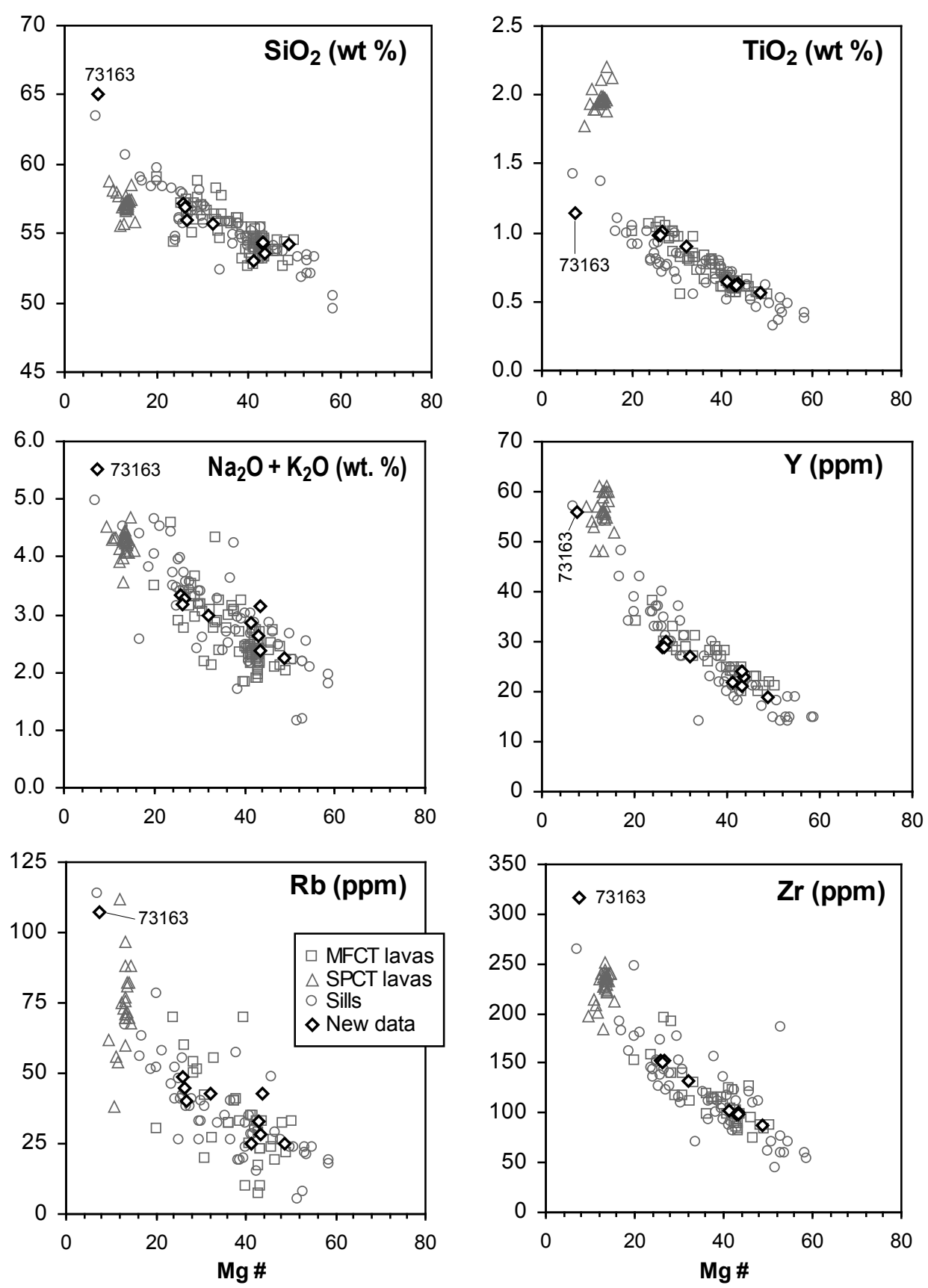

ROSS ET AL., SPECIAL ISSUE, FIG. 12 
a

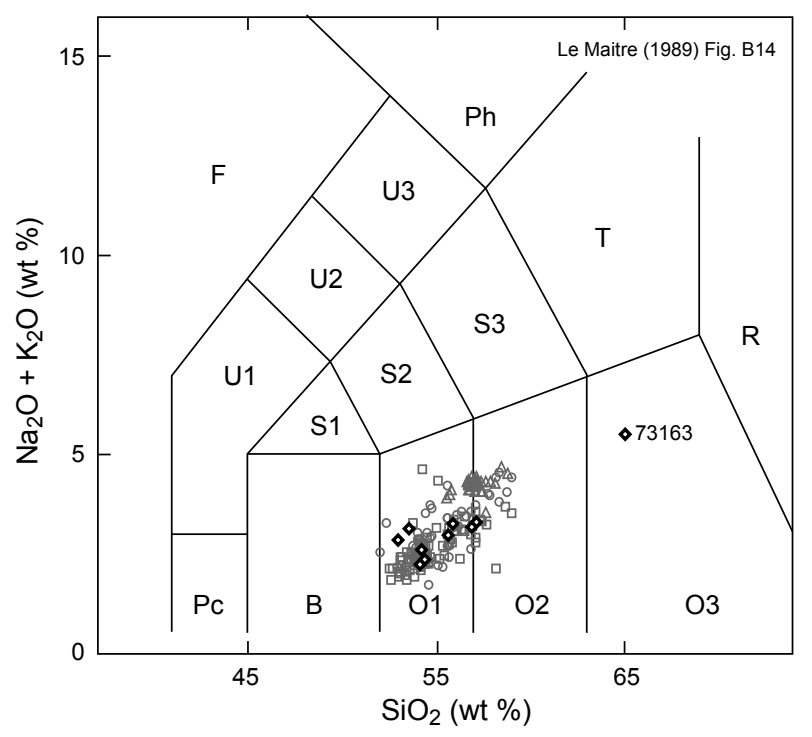

C

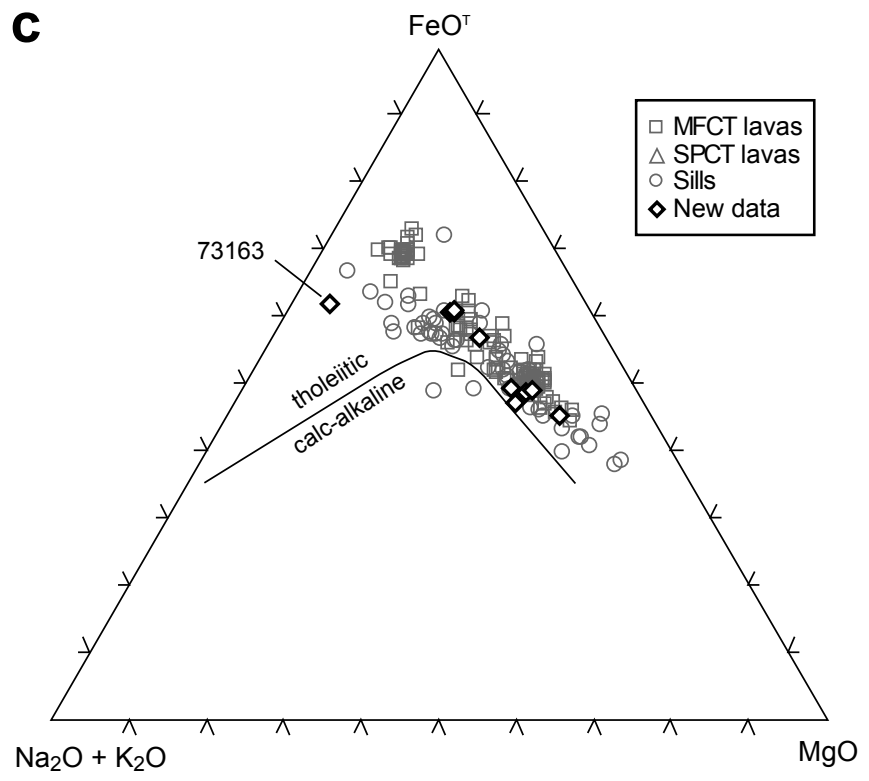

b

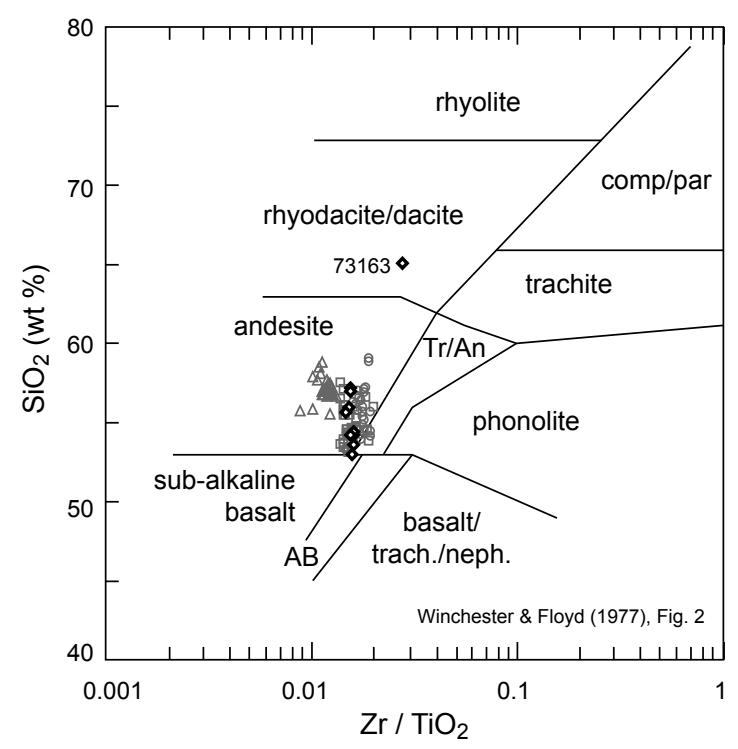

ROSS ET AL., SPECIAL ISSUE, FIG. 13 


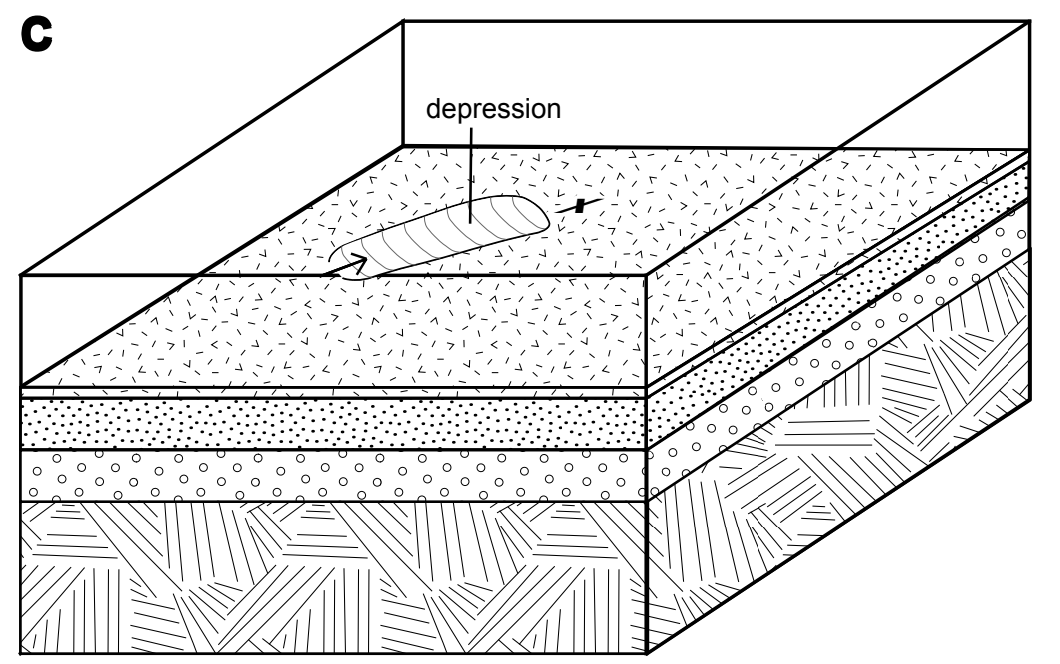

\section{Initiation of mafic magmatism}

Topographic depression down to the Weller at Allan Hills (erosional feature?)

NE-flowing debris avalanche (arrow) to form $\mathrm{m}_{1}$, up to $180 \mathrm{~m}$ thick

Relief and unstable slopes at source of debris avalanche (not shown)

Intrusion of Ferrar magmas in source area (possible avalanche trigger)

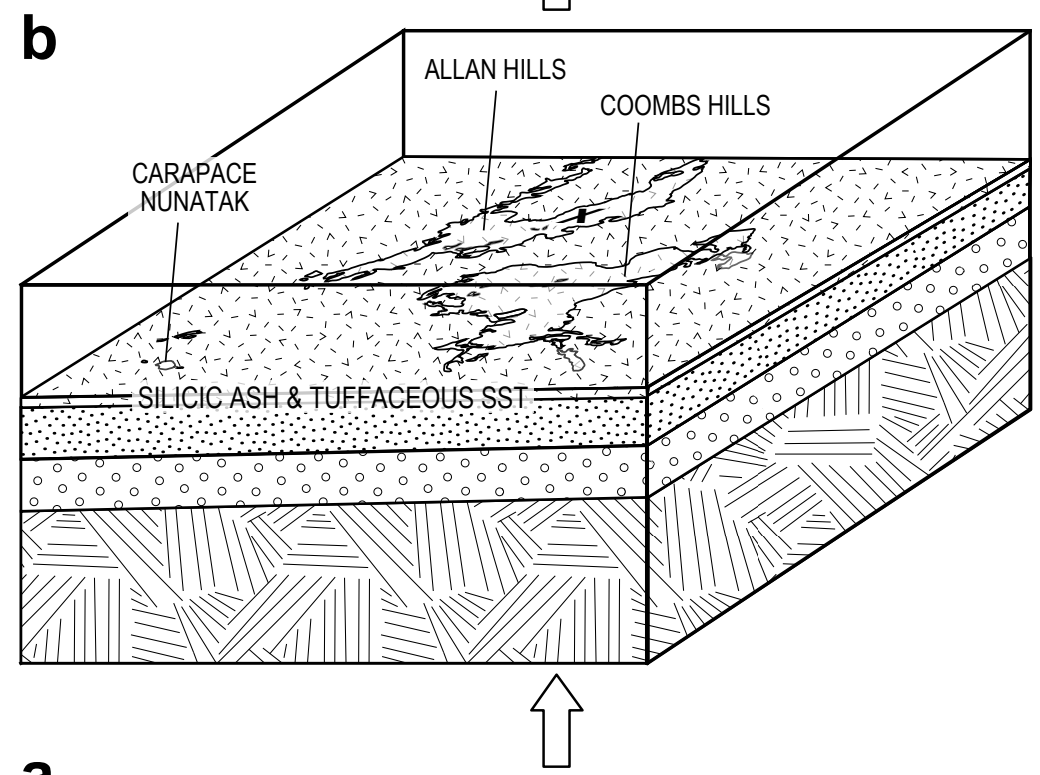

\section{Fall of silicic ash from unknown source (early Jurassic?)}

Siliciclastic (Beacon) system still active (not shown)

Outline of present outcrops shown for reference only

"X" = Roscollyn Tor in NE Allan Hills

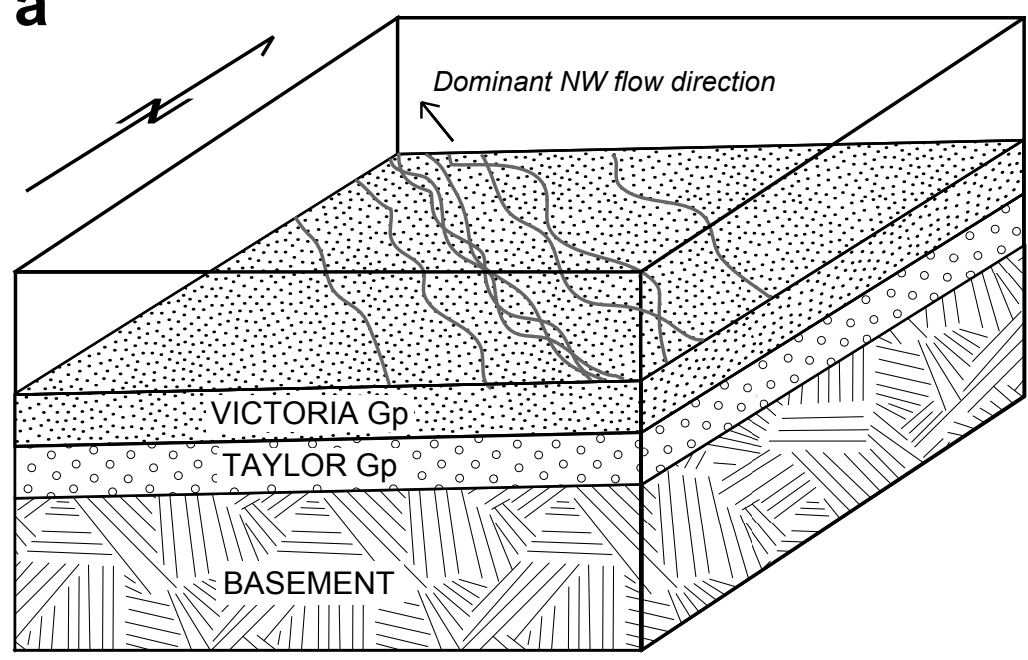

\section{Deposition of Victoria Gp}

Weller Coal Measures to Lashly Fm, PermianTriassic)

Fluvial setting ( $w /$ minor lakes)

\section{Not shown:}

i. Marine transgression in the early Devonian

ii. Deposition of the first $1 / 2$ of the Taylor Gp in shallow marine to subaerial envir. (Windy Gully Sst to Altar Mountain Fm.)

iii. Deposition of second $1 / 2$ of Taylor Gp in NE sloping flood plain (Arena Sst \& Beacon Heights Orthoqtz.)

iv. Contin. glaciation late Carbon. to Permian; deposition of tillite and other seds in valleys

ROSS ET AL., SPECIAL ISSUE, FIG. 14 


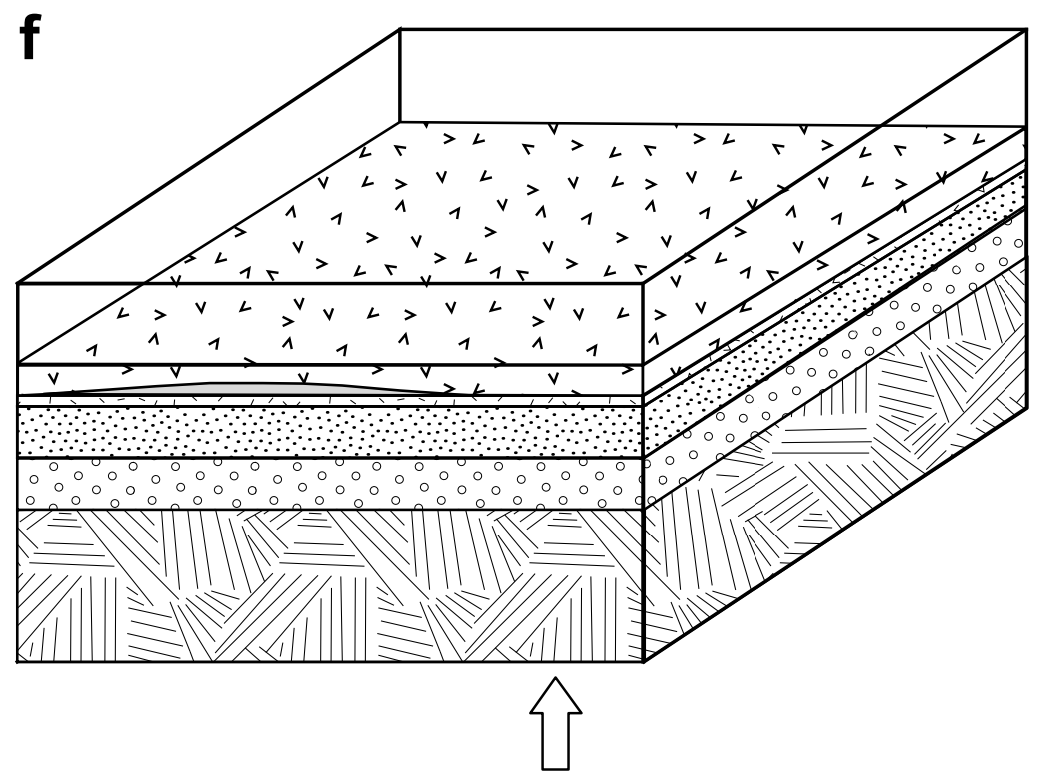

e
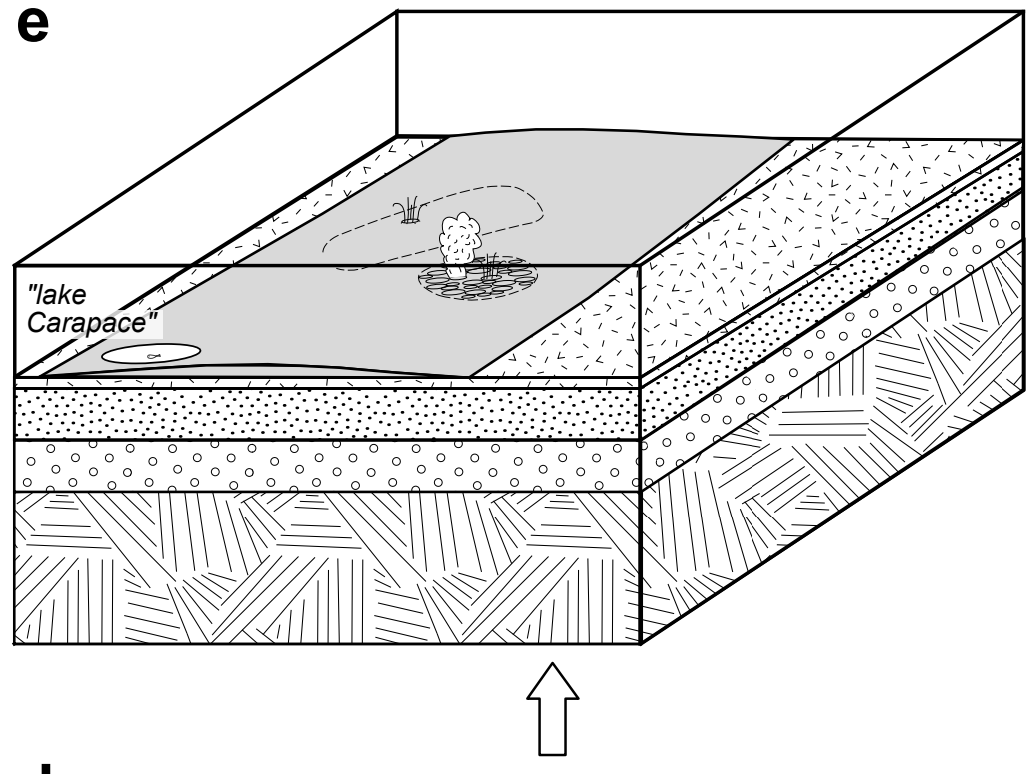

d

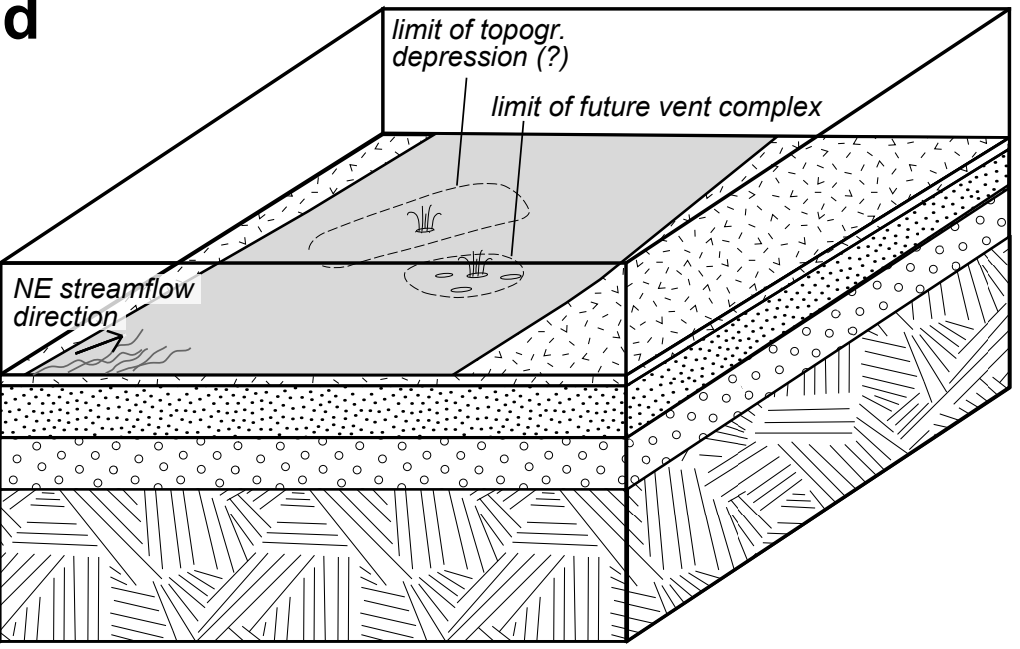

Flood lavas

\section{('Kirkpatrick time')}

Thick subaerial lavas erupted in rapid sucession (locally subaqueous, e.g. base of Carapace Nun section, top of Mt Brooke section)

Occasional explosive eruptions

Occasional breaks in eruption of flood lavas = siliciclastic sedimentation

\section{More mafic volcaniclastic deposits (late 'Mawson time')}

Lacustrine deposits in uppermost Carapace Sandstone

Vent complex fully developed at Coombs Hills; tropospheric eruption plumes

Depression filled by $\mathrm{m}_{2}$ at Allan Hills; some local vents active (block-rich layers, etc.)

Overall Mawson distribution hypothetical; could have concave bottom, rather than convex top as shown here, if subsidence occurs; could be complicated by intrusion of Ferrar Dolerite sills \& tectonic-related relief

\section{First mafic volcaniclastic deposits (early 'Mawson time')}

Carapace Sandstone deposited in alluvial plain; includes fragments of glassy basalt (more vents to the SW?)

First vents at Coombs Hills; both intra-vent and surface deposits (not shown)

Depression being filled by Mawson $\mathrm{m}_{2}$ at Allan Hills; some local vents (tuff rings, etc.)

Grey zone $=$ possible area of deposition for Mawson Fm \& correlatives 